\title{
Disclosure Frequency Induced Myopia and the Decision to be Public
}

\author{
Kevin K. Li \\ likevin@ucr.edu \\ School of Business Administration \\ University of California, Riverside \\ and \\ Vicki W. Tang** \\ wt29@georgetown.edu \\ McDonough School of Business \\ Georgetown University
}

This version: September 2017

\footnotetext{
We appreciate helpful comments from seminar participants at Georgetown University and 2017 Asia Bureau of Finance and Economic Research conference, especially the insightful comments from Turan Bali, Patricia Dechow and Allison Koester.

**Corresponding author. Hariri Building Room 590, McDonough School of Business, Georgetown University, 37 th and O Streets, NW, Washington, DC 20057.
} 


\title{
Disclosure Frequency Induced Myopia and the Decision to be Public
}

\begin{abstract}
This study examines whether disclosure frequency induced myopia influences the types of firms that go public and their choice of listing exchanges if they decide to do so. We find that the incentive to stay private in order to avoid disclosure frequency induced myopia creates a downward kink in the relation between the length of the cash conversion cycle and the proportion of public firms at the industry level around the time frame that corresponds to the mandatory reporting interval. Second, at the firm level, public firms with longer cash conversion cycles relative to industry peers are more likely to list on exchanges that require less frequent mandatory disclosure to minimize disclosure frequency induced myopia. Furthermore, when the mandatory reporting frequency increased from semi-annual to quarterly, we observe a sharper decline in the percentage of public firms from industries whose cash conversion cycles are between one quarter and two quarters relative to those from other industries both in the United States and in the United Kingdom.
\end{abstract}




\section{Introduction}

This study builds on the theoretical framework of Gigler et al. [2014] and examines empirically whether disclosure frequency induced myopia influences the types of firms that go public and their choice of listing exchanges if they decide to do so. Gigler et al. [2014] relate managerial myopia explicitly to the frequency of financial reporting. They define mandatory disclosure as infrequent (frequent) when cumulative cash payoffs from a project are complete (incomplete) by the end of the reporting period and conclude that managers have an incentive to be myopic only under the scenario of frequent reporting.

In practice, a firm has multiple projects concurrently, and the choice of a specific project (long-term versus short-term) is unobservable. Cash payoffs are observable, however, only on an aggregate basis for all projects. Analogous to Gigler et al. [2014], we classify mandatory reporting of a given interval as infrequent (frequent) when the mandatory reporting interval is longer (shorter) than a firm's average length of cash payoffs from all projects. Empirically, we use the length of the cash conversion cycle as a proxy for the average length of cash payoffs from all projects. The length of the cash conversion cycle is defined as the average amount of time each net input dollar (including raw material, labor, and technology) is tied up in the production and sales process before it is converted into cash flow. Firms with longer cash conversion cycles are more likely to have projects whose cash payoffs are not complete within a given mandatory reporting interval.

To validate the use of the cash conversion cycle as a proxy for the average length of cash payoffs from all projects, we find that publicly listed firms with cash conversion cycles longer than one quarter cut research and development expenses in the year of seasoned equity offerings (SEOs) to a greater extent than those with cash conversion cycles shorter than one quarter. 
Furthermore, the difference in research and development expenses between these two groups in the year of SEOs is more pronounced when investors are impatient. Both sets of empirical results are consistent with the predictions from Gigler et al. [2014] that in response to price pressure from the public market, disclosure frequency induced myopia is present only under the scenario of frequent reporting, and that disclosure frequency induced myopia increases as price pressure from the public market increases.

We then examine the effect of disclosure frequency induced myopia on the types of firms that go public and the choice of listing exchanges if they decide to do so. Disclosure frequency induced myopia is more (less) likely to be present when the average length of cash payoffs from all projects is longer (shorter) than the frequency of mandatory disclosure, which corresponds to the scenario of frequent (infrequent) reporting in Gigler et al. [2014]. Accordingly, the mandatory quarterly reporting in the United States creates a greater incentive for firms whose average length of cash payoffs from all projects is longer than one quarter to stay private to avoid disclosure frequency induced myopia, compared with firms whose average length of cash payoffs from all projects is shorter than one quarter.

Given that the average length of cash payoffs from all projects contains a significant industry-specific component, we test the cross-sectional prediction at the industry level. Empirically, we look at the cross-section of all public and private firms in the United States and measure the proportion of public firms relative to all firms (including both private and public firms) at the industry level at a given time. Using the U.S. Census of Manufactures and Compustat, we find that, compared to the corresponding change in industries whose cash conversion cycles are shorter than one quarter, a one-day increase in the cash conversion cycle in industries whose cash conversion cycles are longer than one quarter is associated with an 
additional $0.013 \%$ decrease in the proportion of public firms relative to the mean. The evidence suggests that disclosure frequency induced myopia is more pronounced when the average length of cash payoffs from all projects exceeds the frequency of mandatory reporting, which deters (encourages) firms in those industries from entering (to exit) the public market.

Given that the average length of cash payoffs from all projects also contains a firmspecific component, we explore the effect of the within-industry variation in disclosure frequency induced myopia on the choice of listing exchanges. Listing exchanges in different jurisdictions impose different mandatory reporting frequencies. For public firms, we hypothesize that firms with longer cash conversion cycles relative to their industry peers are more likely to choose a listing exchange that imposes less frequent periodic mandatory reporting to minimize disclosure frequency induced myopia. Empirically, we find that firms domiciled in the United Kingdom (U.K.) with cash conversion cycles longer than those of their industry peers were less likely to be listed on U.S. exchanges during the period from 2002 to 2006, when the frequency of mandatory reporting was quarterly in the United States and semi-annual in the U.K.

Next, we examine the effect of the time-series variation in the frequency of mandatory disclosure on the types of firms that go public. Gigler et al. [2014] suggest that increasing the frequency of financial reporting increases price pressure, and this increased price pressure could induce firms to choose myopic projects in order to boost their current market prices. Intuitively, when reporting intervals are shortened as a result of increased disclosure frequency, the same firm is more likely to have projects whose cumulative cash payoffs are not complete within the shortened reporting interval. The increased incentive to be myopic is especially salient for firms whose average length of cash payoffs from all projects is shorter than the old reporting interval but longer than the new reporting interval because those firms view the old reporting regime as 
infrequent, but view the new reporting regime as frequent. The shift from infrequent to frequent financial reporting creates a new incentive for those firms to stay private to avoid disclosure frequency induced myopia.

The empirical results from both United States and the U.K. suggest that an increase in the frequency of mandatory reporting deters (encourages) more firms from entering (to exit) the public markets to avoid disclosure frequency induced myopia, especially in industries whose average length of cash payoffs from all projects is shorter than the old reporting interval but longer than the new reporting interval. More specifically, in the United States, compared to the corresponding change in other industries, the proportion of public firms in industries whose cash conversion cycles are between one quarter and two quarters decreased by an additional $0.864 \%$ from the period between 1965 to 1969 when the frequency of mandatory reporting was semiannual to the period between 1970 to 1974 when the frequency of mandatory reporting was quarterly. In the U.K., public firms from industries whose cash conversion cycles are between one quarter and two quarters accounted for a smaller percentage of all public firms in the period between 2007 and 2011 when the frequency of mandatory reporting was quarterly compared to the period between 2002 and 2006 when the frequency of mandatory reporting was semi-annual, after controlling for normal fluctuations in industry composition during these periods using U.S. firms.

This study contributes to multiple strands of the literature. First, to the best of our knowledge, this is the first study to investigate whether disclosure frequency induced myopia influences a firm's decision to go public and a firm's choice of the listing exchange. We provide new empirical evidence on the economic consequences of mandatory reporting frequency. This study complements prior research by suggesting that the public market's focus on short-term 
earnings induces not only myopic managerial behaviors in publicly traded firms, but also influences a firm's decision on whether to go public and the firm's choice of listing exchanges.

Second, this study provides new insights into the ongoing debate on the frequency of mandatory disclosure. More specifically, we find that an increase in the frequency of mandatory reporting deters (encourages) firms from industries whose cash conversion cycles are shorter than the length of the old reporting interval but longer than the length of the new reporting interval from entering (to exit) the public markets. The primary argument for increasing disclosure frequency rests on enhancing timeliness and transparency. A key argument against increasing disclosure frequency is that more frequent reporting forces managers of publicly traded firms to focus on short-run performance at the expense of long-run performance. Our findings suggest that regulators deliberating an increase in mandatory reporting frequency also need to consider the impact of such a change on the types of firms that choose to go public and the choice of listing exchanges.

Furthermore, this study contributes to the literature on stock listing choice in an international context. Prior studies largely examine the cross-listing decision from the perspective of investor protection and corporate governance (e.g., Karolyi [2012]). A dominant paradigm is the bonding hypothesis proposed by Coffee [1999]. This study, in contrast, examines the choice of listing exchanges from an entirely new angle by investigating whether disclosure frequency induced myopia also plays a role in the decision while holding constant the origin country and the destination country. The findings suggest that for public firms, the firm-level cash conversion cycle relative to industry peers influences U.K.-domiciled firms' decision to list in the United States, thereby providing supporting evidence that mandatory disclosure requirements have important economic consequences on the choice of listing exchanges. 
Finally, this study complements the strand of literature that suggests an important interaction between capital market and product market behaviors (e.g., Chevalier [1995]; Hellman and Puri [2000]; Campello [2006]). For example, Chevalier [1995] and Campello [2006] find that the debt-to-equity ratio influences a firm's decisions about the capacity and form of strategic alliances. Hellman and Puri [2000] find that the stake taken by venture capitalists influences a firm's product market innovation strategy. All those studies examine whether and how a given financing choice influences product market behavior. In contrast, we examine how a given product market attribute influences the choice of whether and where to raise capital from the public market. Specifically, this study suggests that the length of the cash conversion cycle influences a firm's decision to access the public market and this influence varies with disclosure regulations in the capital market.

The remainder of the paper is organized as follows. Section 2 develops the hypotheses. Section 3 discusses the research design and sample selection. Section 4 presents empirical results. Section 5 concludes.

\section{Hypothesis development}

Prior theoretical studies suggest that price pressures from the public market affect managers' decisions. For instance, Stein [1989] suggests that even though the market is fully efficient to the extent that the market correctly anticipates the equilibrium actions of the manager and correctly prices the firm, price pressure from the public market will still cause the manager to behave myopically when the market is unable to directly observe the manager's actions. Furthermore, Gigler et al. [2014] relate managerial myopia explicitly to the frequency of financial reporting and to the degree of impatience in the capital market. They conclude that 
price pressure created by frequent reporting induces managers to adopt a short-term perspective (myopia) in choosing projects.

Throughout the study, we use the theoretical framework from Gigler et al. [2014] to develop empirical hypotheses. Mandatory disclosure is defined as infrequent (frequent) when the cumulative cash payoffs from a project are complete (incomplete) by the end of the reporting period. Assuming there are no conflicts of interest between corporate managers and shareholders, ${ }^{1}$ Gigler et al. [2014] predict that managers have an incentive to be myopic only under the scenario of frequent reporting when the firm's specific project choice (long term versus short term) is unobservable. This is largely because frequent reporting results in price pressures that are analogous to the pressure caused by the premature evaluation of any action whose value is probabilistically evident only over the long term. These premature evaluations are tempered by subsequent evaluations, but the damage caused by early evaluations cannot be overcome when shareholders are sufficiently impatient.

One could argue that accounting accruals mitigate the timing issue of cash flows (e.g., Dechow [1994]), and, therefore, the pressure caused by the premature evaluation is mitigated by informative accounting accruals. However, Ewert and Wagenhofer [2005] suggest that tighter accounting results in a strengthened relationship between accounting earnings and underlying transactions, which makes accounting accruals more "value relevant" and increases managerial incentives to engage in real earnings management (myopic behavior), such as cutting research and development costs. Therefore, the relation between accounting accruals and managerial myopia is ambiguous. This study adopts the assumption in Gigler et al. [2014] that cost outlays are perfectly measured and cash payoffs are independent intertemporally, and, therefore, there is no scope for informative accounting accruals.

\footnotetext{
${ }^{1}$ In particular, managers act according to the preferences of the current shareholders.
} 
In practice, a firm has multiple projects concurrently and a specific project choice (long term versus short term) is unobservable. Therefore, cash payoffs are observable only on an aggregate basis for all projects. Analogous to Gigler et al. [2014], we classify mandatory reporting of a given interval as infrequent (frequent) when the duration of the reporting period is longer (shorter) than a firm's average length of cash payoffs from all projects. Accordingly, disclosure frequency induced myopia is more likely to be present when the mandatory reporting interval is shorter than a firm's average length of cash payoffs from all projects, which corresponds to the frequent reporting scenario. In contrast, disclosure frequency induced myopia is less likely to be present when the mandatory reporting interval is longer than a firm's average length of cash payoffs from all projects, which corresponds to the infrequent reporting scenario.

Empirically, we use the length of the cash conversion cycle as a proxy for the average length of cash payoffs from all projects. The frequency of mandatory reporting for publicly listed firms in the United States is quarterly. If the cash conversion cycle is a valid empirical proxy for the average length of payoffs from all projects, it is expected that, in response to price pressure from the public market, managers in publicly traded firms whose cash conversion cycles are longer than one quarter exhibit a greater extent of myopia than those in firms whose cash conversion cycles are shorter than one quarter. Furthermore, the more impatient investors are, the greater the price pressure from the public market, and the greater the difference in managerial myopia between firms whose cash conversion cycles are longer than one quarter and those whose cash conversion cycles are shorter than one quarter. This leads to the first hypothesis:

Hla: Managerial myopia in publicly traded firms whose cash conversion cycles are longer than one quarter is greater than that in firms whose cash conversion cycles are shorter than one quarter.

H1b: When investors are impatient, the difference in managerial myopia between firms with cash conversion cycles longer than one quarter and those with cash conversion cycles shorter than one quarter is more pronounced. 
Anecdotal evidence suggests that mandatory reporting is a factor that potentially discourages firms from going public. For example, Jonathan Klein, chief executive of Getty Images, commented, "We moved swiftly and adjusted our cost base, invested in our employees and were able to acquire our then second largest competitor at a knock-down price. . . All of this was possible as a private company without the issues of quarterly reporting, providing guidance on earnings, a volatile stock price and external pressures” (Upbin [2013]).

The anecdotal evidence raises the interesting question of whether disclosure frequency induced myopia is an economically significant factor in a firm's decision to become a publicly traded firm. If so, the cross-sectional variation in disclosure frequency induced myopia is expected to influence the types of firms that go public. On the one hand, firms with longer length of cash payoffs from all projects have a greater need for external funds, and thus are more likely to access external markets, including the public equity market. On the other hand, disclosure frequency induced myopia deters firms from entering the public equity market. Disclosure frequency induced myopia is more (less) likely to be present for firms whose average length of cash payoffs from all projects is longer (shorter) than the mandatory reporting interval (Gigler et al., 2014). Accordingly, the relation between the average length of cash payoffs from all projects and the tendency to be public is not linear, but, rather, depends on the time frame into which the average length of cash payoffs from all projects falls. For firms whose average length of cash payoffs from all projects is longer than the mandatory reporting interval, the above-mentioned two effects work in opposite directions. In contrast, the incentive to stay private to avoid disclosure frequency induced myopia is much weaker for firms whose average length of cash payoffs from all projects is shorter than the mandatory reporting interval. For the latter group, 
the effect of a greater need for external financing for firms with a longer average length of cash payoffs from all projects dominates. In summary, the extra incentive to stay private in order to avoid disclosure frequency induced myopia triggers a downward kink in the relation between the average length of cash payoffs from all projects and the likelihood of being public around the time frame that corresponds to the mandatory reporting interval.

Given that the average length of cash payoffs from all projects contains a significant industry-specific component, we hypothesize that, compared with the corresponding change in industries whose cash conversion cycles are shorter than one quarter, an increase in the length of the cash conversion cycle is associated with an additional decrease in the proportion of public firms in industries whose cash conversion cycles are longer than one quarter. This leads to the second hypothesis:

H2: Disclosure frequency induced myopia is more pronounced when the length of the cash conversion cycle exceeds the mandatory reporting interval, which deters (encourages) more firms in those industries from entering (to exit) the public market.

Furthermore, if a firm decides to go public, disclosure frequency induced myopia is likely to influence a firm's choice of listing exchange. Listing exchanges in different jurisdictions impose different frequencies of mandatory reporting. For instance, during the period from 2002 to 2006, the frequency of mandatory reporting was quarterly in the United States and semiannual in the U.K. In addition to the significant industry-specific component, the average length of cash payoffs from all projects also contains a firm-specific component. Relative to industry peers, a firm whose average length of cash payoffs from all projects is 120 days is more likely to view the quarterly reporting regime in the United States as frequent than will its industry peer whose average length of cash payoffs from all projects is 80 days. Accordingly, we hypothesize that a firm with a longer average length of cash payoffs from all projects relative to its industry 
peers is more likely to choose a listing exchange that imposes less frequent mandatory reporting to minimize disclosure frequency induced myopia. This leads to the third hypothesis:

H3: Public firms with cash conversion cycles longer than those of their industry peers are more likely to choose a listing exchange that imposes less frequent mandatory reporting to mitigate disclosure frequency induced myopia.

Finally, we examine the effect of the time-series variation in the frequency of mandatory disclosure on the types of firms that go public. More specifically, we explore the changes in the frequency of mandatory reporting from semi-annual to quarterly in both the United States and the U.K. In the United States, the Securities and Exchange Commission required public firms to change from semi-annual to quarterly reporting in 1970. Starting January 20, 2007, the U.K. implemented the European Union Transparency Directive, which changed the reporting frequency of public firms listed in the U.K. from semi-annual to quarterly, even though the newly implemented quarterly reporting requirements were less extensive and stringent than the semi-annual reporting requirements.

Gigler et al. [2014] suggest that increasing the frequency of financial reporting increases price pressure, which could induce a publicly listed firm to choose myopic projects in order to boost its current market price. Intuitively, when reporting intervals are shortened as a result of the increased disclosure frequency, some firms are likely to have projects whose cumulative cash payoffs are not complete within the shortened reporting interval. For instance, if a firm's average length of cash payoffs from all projects is 120 days, most of its projects are complete by semiannual end, but are incomplete at quarter end. The increased incentive to be myopic is especially salient for firms whose average length of cash payoffs from all projects is shorter than the old reporting interval but longer than the new reporting interval because those firms view the old reporting regime as infrequent, but view the new reporting regime as frequent. As disclosure 
frequency induced myopia is more (less) likely to be present under frequent (infrequent) reporting scenario, the shift from infrequent to frequent reporting regime creates a new incentive for managers in those firms to be myopic. Accordingly, we hypothesize that an increase in the frequency of mandatory reporting deters (encourages) more firms from entering (to exit) the public markets to avoid disclosure frequency induced myopia, especially in industries whose average length of cash payoffs from all projects is shorter than the old reporting interval but longer than the new reporting interval. This leads to the fourth hypothesis:

H4: An increase in the frequency of mandatory reporting deters (encourages) more firms from entering (to exit) the public markets to avoid disclosure frequency induced myopia, especially in industries whose cash conversion cycles are shorter than the old reporting interval but longer than the new reporting interval.

\section{Research design and sample selection}

3.1. Managerial myopia, investor impatience, and the length of the cash conversion cycle

According to Gigler et al. [2014], disclosure frequency induced myopia is more likely to be present when mandatory disclosure is frequent and investors are impatient. To validate whether the cash conversion cycle is a good proxy for the average length of payoffs from all projects, we compare managerial myopia in the year of seasoned equity offerings in U.S. public firms partitioned by the length of the cash conversion cycle, controlling for investor impatience.

We measure managerial myopia using real activity management via manipulating research and development expenses. Following Roychowdhury [2006], Cohen and Zarowin [2010] and Zang [2012], we compute abnormal research and development (ARND) expenses as the residual from the following regression:

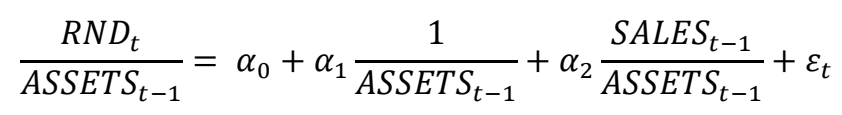


where $\mathrm{RND}_{\mathrm{t}}$ is research and development expense in year $t$. SALES $\mathrm{S}_{\mathrm{t}-1}$ and ASSETS $_{\mathrm{t}-1}$ are sales and total assets in year $t-1$. The regression is estimated cross-sectionally by industry and year for the period from 1987 to 2015 . We require that there be at least eight observations for every industry and year combination. We use the North American Industry Classification System (NAICS) to classify industries because Bhojraj et al. [2003] suggest that the NAICS yields groupings of firms that are more economically related and homogeneous than the Standard Industry Classification (SIC) system. ${ }^{2}$ Firms in finance industries (those for which the first two digits of the NAICS codes are 52 and 53) are excluded because their cash conversion cycle is not well defined.

We compute the length of the cash conversion cycle as the sum of days' sales outstanding in accounts receivables plus days' sales in inventory minus days' sales in accounts payable. Days' sales outstanding in accounts receivables measures the amount of time it takes to collect cash from customers and is calculated as accounts receivable divided by daily sales. Days' sales in inventory measures the amount of time each net input dollar is tied up in the production process and inventory and is calculated as inventory divided by daily cost of goods sold. Days' sales in accounts payable measures the days of operation that are financed by suppliers, that is, the number of days before suppliers are paid, and is calculated as accounts payable divided by daily cost of goods sold. The cash conversion cycle increases with days' sales in inventory and days' sales outstanding in accounts receivables and decreases with days' sales in accounts

\footnotetext{
${ }^{2}$ The NAICS uses a six-digit hierarchical coding scheme to classify all product markets into 20 sectors, 5 of which are goods-producing sectors and 15 of which are services-providing sectors. The NAICS was developed in response to structural changes in the economy. Recent developments in information services, new forms of healthcare provision, expansion of services, and high-tech manufacturing are examples of the structural changes that cannot be studied under the SIC system. Nine new service sectors and 250 new service industries are recognized under the NAICS. The empirical results are robust using SIC codes to classify industries.
} 
payable. We use the median cash conversion cycle over the previous five years as a proxy for the normal level of cash conversion cycle for each firm-year.

Ernstberger et al. [2017] argue that a capital market is more impatient when investors put a stronger emphasis on earlier rather than later future cash flows. Ernstberger et al. [2017] measure investor impatience as the ratio of the return-sensitivity for current year's cash flows relative to the return-sensitivity for subsequent year's cash flows. Because we examine the effects of mandatory disclosure on managerial myopia and the mandatory disclosure frequency in the United States is quarterly, we measure investor impatience as the ratio of the returnsensitivity for current quarter's cash flow relative to the return-sensitivity for subsequent quarter's cash flows. Specifically, we estimate the following regression for each firm-year using five years of data:

$$
R E T_{t}=\beta_{0}+\beta_{1} \frac{\operatorname{CFO}_{q 1}}{\operatorname{ASSETS~}_{t-1}}+\beta_{2} \frac{\mathrm{CFO}_{q 2-q 4}}{\operatorname{ASSETS~}_{t-1}}+\beta_{3} \frac{\mathrm{CFO}_{t+1}}{\operatorname{ASSETS~}_{t-1}}+\mu_{t}
$$

where $\mathrm{RET}_{\mathrm{t}}$ is the buy-hold return over the 12-month period starting four months after the end of fiscal year $t-1$; and $\mathrm{CFO}_{\mathrm{q} 1}, \mathrm{CFO}_{\mathrm{q} 2-\mathrm{q} 4}$, and $\mathrm{CFO}_{\mathrm{t}+1}$ are standardized cash flows from operations of the first quarter of year $t$, the second quarter to the fourth quarter of year $t$, and year $t+1$, respectively. Investor impatience (IMPATIENCE) equals one if the ratio $a b s\left(\beta_{1}\right) /\left(a b s\left(\beta_{2}\right)+\right.$ $\left.a b s\left(\beta_{3}\right)\right)$ is above the industry median, and zero otherwise. ${ }^{3}$

We obtain the seasoned equity offerings sample from the Thomson Reuters SDC New Issue database for the period from 1987 to 2015 . The sample is restricted to firms listed on the New York Stock Exchange, the American Stock Exchange and NASDAQ and excludes initial public offerings, private placements, rights issues, spin-offs, and unit issues. The final sample

\footnotetext{
${ }^{3}$ We use two alternative ratios, $\operatorname{abs}\left(\beta_{1}\right) / \mathrm{abs}\left(\beta_{2}\right)$ and $\operatorname{abs}\left(\beta_{1}\right) / \mathrm{abs}\left(\beta_{3}\right)$, to define investor impatience and obtain similar results.
} 
with sufficient data to compute ARND, cash conversion cycle, and investor impatience includes 369 observations.

\subsection{The length of the cash conversion cycle and the proportion of public firms}

Hypothesis 2 examines whether the incentive to stay private to avoid disclosure frequency induced myopia triggers a downward kink in the relation between the length of cash conversion cycle and the likelihood of being public around the time frame that corresponds to the mandatory reporting interval. In the United States, the mandatory reporting frequency has been quarterly since 1970. To test Hypothesis 2, we collect the total number of firms, both private and public, in a given industry from the Census of Manufactures ${ }^{4}$ and the information about public firms from Compustat for the sample period from 1995 to 2014.

The U.S. census takes place every five years. The latest Census of Manufactures used in the sample was published in 2012. To align the census year with the fiscal year, we use the census data from a given year not only for that year, but also for the two years immediately before and after it. For instance, the number of all firms (NUM_FIRMS_CENSUS) from the 2012 census is aligned with the number of public firms (NUM_PUBLIC) from Compustat for each industry-year observation from 2010 to 2014. Accordingly, for each industry, NUM_FIRMS_CENSUS is identical from 2010 to 2014. Therefore, it is necessary to clusteradjust standard errors in the associated empirical analyses. The industry-level proportion of public firms $\left(\right.$ PROPORTION $\left._{i t}\right)$ is the fraction of the number of public firms (NUM_PUBLIC ${ }_{i t}$ ) relative to the total number of firms (NUM_FIRMS_CENSUS it) for a given industry-year. As the

\footnotetext{
${ }^{4}$ According to the Census of Manufactures, a firm is defined as an aggregation of all establishments that operate under the ownership or control of a single organization. A firm includes all subsidiary organizations, all establishments that are majority-owned by the company or any subsidiary, and all the establishments that can be directed or managed by the company or any subsidiary. A nonpublic firm is defined as privately owned by individuals rather than by a subsidiary of other companies in the Census. Therefore, the number of all firms in an industry is equal to the number of privately held firms plus the number of public firms.
} 
proportional-type variable typically does not satisfy the statistical properties of the ordinary least squares (OLS) estimation, following Draper and Smith [1966], we perform log odds transformation of PROPORTION $\mathrm{it}$. The dependent variable is the log odds (LOG_ODDS $\mathrm{it}_{\text {), }}$ which is measured as $\mathrm{Ln}_{\text {PROPORTION }}$ / $/\left(1-\right.$ PROPORTION $\left.\left._{\mathrm{it}}\right)\right]$.

As the cash conversion cycle of private firms is not measurable due to the lack of available data, we use the median length of the cash conversion cycle of public firms in Compustat in a given industry-year as a proxy for the length of the industry's cash conversion cycle (INDUSTRY_CCC). CCC_LONG1Q is an indicator variable that equals one if INDUSTRY_CCC is longer than one quarter, and zero otherwise. We also measure the three components of cash conversion cycle at the industry level. INDUSTRY_DSO, INDUSTRY_DSI, and INDUSTRY_DPO are the median days' sales outstanding in accounts receivable, the median days' sales in inventory, and the median days' sales in accounts payable, respectively, of public firms in a given industry-year.

We include a set of control variables. Ali et al. [2009] suggest that, in industries with fewer firms, the percentage of large public firms is higher; these firms are more likely to be included on Compustat. Therefore, it is essential to hold the number of firms constant when examining the empirical relationship between the length of the cash conversion cycle and the proportion of public firms across industries. Accordingly, we include the number of firms measured in thousands in a given industry (NUM_FIRMS_CENSUS ${ }_{i t}$ ). We also include the logarithm of the average sales of public firms in a given industry (Ln[INDUSTRY_SALES $\mathrm{it}_{\mathrm{it}}$ ) to control for the differences in size across industries.

Proprietary costs of mandatory disclosure could vary across industries and over time. To the extent that firms in more profitable industries face greater proprietary costs of public 
disclosure, we include industry-level profitability to capture the cross-industry variation in proprietary costs. We measure industry-level profitability using the average gross profit margin (INDUSTRY_GPM) of public firms in Compustat in a given industry-year. ${ }^{5}$ Proprietary costs of mandatory disclosure could vary considerably over time. Survey evidence indicates that segment information is viewed as the most competitively sensitive information. In 1997, the Financial Accounting Standards Board issued Statement of Financial Accounting Standards (SFAS) 131, which requires that public firms use the management approach instead of the industry approach to classify business segments. Under the management approach, segment information is presented based on how management internally evaluates the operating performance of its business units. SFAS 131 increases the number of reported segments and provides more disaggregated information (see Berger and Hann [2003]). Moreover, SFAS 131 allows investors to assess the performance of individual operating segments in the same way as management. We include POST_SFAS131 to capture the potential increase in proprietary costs of mandatory disclosure after SFAS 131. POST_SFAS131 $\mathrm{t}$ is an indicator variable, which equals one if the year is 1997 or later, and zero otherwise.

Implementation costs of mandatory disclosure could vary over time. To the extent that the Sarbanes-Oxley Act of 2002 (SOX) significantly increases the implementation costs of mandatory disclosure requirements (see Engel, Hayes and Wang [2007]), we include POST_SOX $_{t}$ to capture the temporal change in implementation costs. POST_SOX $X_{t}$ is an indicator variable, which equals one if the year is 2002 or later, and zero otherwise. In summary, the specification to test Hypothesis 2 is as follow:

\footnotetext{
${ }^{5}$ We also use price-to-cost margin (INDUSTRY_MARKUP) as an alternative proxy for industry-level profitability and obtain similar results. Following Allayannis and Ihrig [2001], INDUSTRY_MARKUP it is defined as (value of shipments $+\Delta$ inventory-payroll-cost of materials)/(value of shipments $+\Delta$ inventory). The required data are collected from Annual Survey of Manufacturers publications.
} 


$$
\begin{aligned}
& \text { LOG_ODDS } S_{i t}=\propto+\beta_{1} I N D U S T R Y_{-} C C C_{i t}+\beta_{2} C C C_{-} L O N G 1 Q_{i t}+\boldsymbol{\beta}_{3} \text { CCC_LONG1Q }_{\boldsymbol{i t}} * \text { INDUSTRY_CCC } \boldsymbol{i t} \\
& +\beta_{4} N U M_{-} \text {FIRMS_CENSUS } i t+\beta_{5} \operatorname{Ln}(\text { INDUSTRY_SALES })_{i t}+\beta_{6} I N D U S T R Y_{-} G P M_{i t} \\
& +\beta_{7} \text { POST_SFAS131 }+\beta_{8} P O S T \_S O X_{t}+\varepsilon_{i t}
\end{aligned}
$$

The variable of interest is the coefficient on the interaction term between INDUSTRY_CCC and CCC_LONG1Q. We expect $\beta_{3}$ to be negative. The sample for the empirical tests of Hypothesis 2 includes the 5,842 industry-year observations from 401 manufacturing industries between 1995 and 2014.

Regression (4) summarizes the specification that explores the effects of the three components of the industry's cash conversion cycle on the proportion of public firms:

$$
\begin{aligned}
& \text { LOG_ODDS } S_{i t}=\propto+\beta_{1} C C C_{-} L O N G 1 Q_{i t}+\beta_{2} I N D U S T R Y \_D S I_{i t}+\boldsymbol{\beta}_{3} \text { CCC_LONG1Q } \boldsymbol{Q}_{i t} * \text { INDUSTRY_DSI } \boldsymbol{I}_{\text {it }} \\
& +\beta_{4} I N D U S T R Y \_D S O_{i t}+\beta_{5} \text { CCC_LONG1Q } Q_{i t} * \text { INDUSTRY_DSO } \boldsymbol{\beta}_{i t}+\beta_{6} I N D U S T R Y \_D P O_{i t} \\
& +\beta_{7} \text { CCC_LONG1Q } \boldsymbol{Q}_{i t} * \text { INDUSTRY_DPO }{ }_{i t}+\beta_{8} N U M_{-} F I R M S_{-} C E N S U S_{i t} \\
& +\beta_{9} \operatorname{Ln}(\text { INDUSTRY_SALES })_{i t}+\beta_{10} \text { INDUSTRY_GPM } i t+\beta_{11} \text { POST_SFAS131 } t \\
& +\beta_{12} \text { POST_SOX }+\boldsymbol{\varepsilon}_{i t}
\end{aligned}
$$

The variables of interest are the coefficients on the three interaction terms. We expect $\beta_{3}$ and $\beta_{5}$ to be negative and $\beta_{7}$ to be positive.

\subsection{Length of cash conversion cycle and the choice of listing exchanges}

Hypothesis 3 examines the relation between the length of cash conversion cycle and the firm's choice of listing exchange when it goes public. Prior to the implementation in the U.K. of the European Union Transparency Directive in 2007, U.K. public firms were required to file only semi-annual and annual reports. However, if a U.K.-domiciled firm chose to list on U.S. stock exchanges, it would be subject to quarterly reporting. To test Hypothesis 3, we employ the Worldscope annual database to identify U.K.-domiciled firms that were listed on the U.K. or U.S. stock exchanges from 2002 to 2006 , the four-year period prior to the change in mandatory 
reporting frequency in the U.K. ${ }^{6}$ We define the indicator variable for U.K.-domiciled firms listed in the United States (USLIST), which equals one for U.K. firms listed in the U.S. markets, and zero for U.K. firms listed in the U.K. markets. To capture difference between a firm's cash conversion cycle and that of its industry peers, we compute the industry-adjusted cash conversion cycle in two alternative ways. CCC_DM1 (2) is a firm's cash conversion cycle minus industry average cash conversion cycle, where industry average cash conversion cycle is computed every year using the U.K. firms listed in the U.K. (both U.S. and U.K.) markets. Industries are defined at the two-digit industry group level in Worldscope (Item 6011). Financial industries (Item 6011 between 4310 and 4395) are excluded. To control for the differences in listing requirements between U.S. and U.K. exchanges, we include the logarithm of SALES (Item 7240) and return on assets (ROA) — operating income (Item 1250) divided by total assets (Item 2999) — as control variables. The sample to test Hypothesis 3 includes 8,120 firm-year observations from 2002 to 2006 and regression (5) summarizes the specification:

$$
\begin{aligned}
& U_{S L I S T} T_{i t}=\alpha+\boldsymbol{\beta}_{1} \boldsymbol{C C C}_{i t}+\beta_{2} R O A_{i t}+\beta_{3} \operatorname{Ln}(S A L E S)_{i t}+\varepsilon_{i t} \\
& \text { USLIST }_{i t}=\alpha+\boldsymbol{\beta}_{\mathbf{1}} \text { CCC_DM1 } \mathbf{1}_{i t}+\beta_{2} R O A_{i t}+\beta_{3} \operatorname{Ln}(S A L E S)_{i t}+\varepsilon_{i t} \\
& \text { USLIST }_{i t}=\alpha+\boldsymbol{\beta}_{\mathbf{1}} \text { CCC_DM2 }_{i t}+\beta_{2} R O A_{i t}+\beta_{3} \operatorname{Ln}(S A L E S)_{i t}+\varepsilon_{i t}
\end{aligned}
$$

The variable of interest is the coefficient on the raw/industry adjusted cash conversion cycle. We expect $\beta_{1}$ to be negative.

\subsection{Changes in disclosure frequency and changes in the proportion of public firms}

Hypothesis 4 examines the effects of an increase in mandatory disclosure frequency on firms' likelihood to be public. We take advantage of two natural experiments in the changes of the mandatory disclosure frequency from semi-annual to quarterly in 1970 for U.S. firms and 2007 for U.K. firms.

\footnotetext{
${ }^{6}$ The sample starts in 2002 to minimize the potential confounding effects of SOX on the implementation costs of mandatory disclosure requirements (see Engel, Hayes and Wang [2007]).
} 


\subsubsection{The U.S. sample of change in mandatory reporting frequency}

For the U.S. sample, we manually collect the number of all firms (NUM_FIRMS_CENSUS) in each industry from the 1967 and 1972 Census of Manufactures. ${ }^{7}$ To align the census year with the fiscal year, we use the census data from a given year not only for that year but also for the two years immediately before and after it. For instance, the data from the 1967 census are assigned to 1965 to 1969 and are aligned with public firms' data from Compustat.

Because NAICS was not available in these early censuses, we use the SIC system to classify industries. SIC went through major revisions in 1972 and 1987. The SIC codes in Compustat are published by the United States Office of Management and Budget in their 1987 edition of the SIC Manual. To ensure the industry classifications are consistent over time and across different data sources, we manually collect the composition of 1972 SIC industries based on 1967 SIC codes from table 1C of the industry group reports from the 1972 Census of Manufactures. Using this information, we create a 1967 SIC to 1972 SIC concordance table, that is, the percentage of 1967 SIC industries mapped into 1972 SIC definitions. The percentage is calculated as 1972 value of shipments for 1972 SIC definitions divided by total 1972 value of shipments for 1967 SIC definitions. A percentage of "100" indicates that a 1967 SIC code is entirely mapped into a 1972 SIC code, which also includes several 1967 SIC codes combined to form a new 1972 SIC code. A percentage less than "100" indicates that a 1967 SIC code is split into several 1972 SIC codes, which we exclude from the sample to ensure a reliable map from the old definitions to the new definitions. We obtain a similar 1972 SIC to 1987 SIC

\footnotetext{
${ }^{7}$ Bureau of the Census, 1967 Census of Manufactures, https://archive.org/details/1967censusofmanu21unse; Bureau of the Census, 1972 Census of Manufactures, https://archive.org/details/1972censusofmanu21unse.
} 
concordance table from the NBER-CES Manufacturing Industry Database. ${ }^{8}$ We then use these two concordance tables to map the data from the 1967 and 1972 Census of Manufactures into the 1987 SIC definitions. The process results in a sample of 880 industry-year observations from 97 manufacturing industries for the period from 1965 to 1974.

We use the median length of the cash conversion cycle of public firms in a particular industry (INDUSTRY_CCC) measured between 1965 and 1969 to capture the normal industrylevel cash conversion cycle before the change of mandatory reporting frequency. CCC_1Q2Q $Q_{i}$ is an indicator variable, which equals one if INDUSTRY_CCC measured between 1965 and 1969 is longer than one quarter and shorter than two quarters, and zero otherwise. To capture the change of mandatory reporting frequency from semi-annual to quarterly, we use an indicator variable USQTR $\mathrm{t}_{\mathrm{t}}$, which equals one if the year is between 1970 and 1974, and zero if the year is between 1965 and 1969. Regression (6) summarizes the specification to test Hypothesis 4 using the U.S. sample:

$$
\begin{aligned}
& \text { LOG_ODDS } i t=\propto+\beta_{1} I N D U S T R Y \_C C C_{i t}+\beta_{2} U S Q T R_{t}+\beta_{3} C C C_{-} 1 Q 2 Q_{i}+\boldsymbol{\beta}_{\mathbf{4}} \text { CCC_1Q2Q }_{\boldsymbol{i}} * \boldsymbol{U S Q T T \boldsymbol { R } _ { \boldsymbol { t } }} \\
& +\beta_{5} N U M_{-} \text {FIRMS_CENSUS } S_{i t}+\beta_{6} \operatorname{Ln}(\text { INDUSTRY_SALES })_{i t}+\beta_{7} I N D U S T R Y \_G P M_{i t}++\varepsilon_{i t}
\end{aligned}
$$

The variable of interest is the coefficient on the interaction term between USQTR and CCC_1Q2Q, which captures the comparison between the change in the proportion of public firms in industries whose cash conversion cycles are longer than one quarter but shorter than two quarters and the corresponding change in the remaining industries, that is, a difference-indifferences comparison. We expect $\beta_{4}$ to be negative.

\subsubsection{The U.K. sample of change in mandatory reporting frequency}

For the U.K. sample, we use a difference-in-differences research design to examine whether the distribution of public firms from a particular industry in the U.K. changed in

\footnotetext{
${ }^{8}$ National Bureau of Economic Research, http://www.nber.org/nberces/.
} 
response to the change in the frequency of mandatory reporting. In particular, we compare the industry composition of all public firms in the U.K. during the period from 2007 to 2011, when the frequency of mandatory reporting was quarterly, to that during the period from 2002 to 2006, when the frequency of mandatory reporting was semi-annual. ${ }^{9}$ To mitigate the concern that other concurrent factors influence a firm's decision to enter or exit a particular industry, we use the industry composition of all public firms in the United States as the benchmark. The United States is an appropriate benchmark because the frequency of mandatory reporting is quarterly during the corresponding periods.

We use the Worldscope annual database to obtain financial data for public firms in the U.K. and the United States and Worldscope industry groups (Item 6011) to classify industries to ensure consistent classification between the U.K. and U.S. firms. Financial industries (Item 6011 between 4310 and 4395) are excluded from the sample. To capture the normal industry-level cash conversion cycle for U.K. firms prior to the change of mandatory reporting frequency, we compute the industry median cash conversion cycle of U.K. public firms during the period from 2002 to 2006. The indicator variables, CCC_1Q, CCC_1Q2Q, and CCC_2Q, equal one if a firm belongs to industries whose median cash conversion cycle measured over the period from 2002 to 2006 is less than one quarter, between one quarter and two quarters, or more than two quarters, respectively, and zero otherwise. We use public firms in the United States as the benchmark and assign the U.S. firms to the above-defined three groups based on their industry membership. The indicator variable for the change in mandatory disclosure frequency, UKQTR, equals one for observations between 2007 and 2011, and zero for observations between 2002 and 2006.

\footnotetext{
${ }^{9}$ Because we use U.S. firms as the control group and SOX was enacted in 2002, we start the sample from 2002 to minimize the potential confounding effects of SOX on the implementation costs of mandatory disclosure requirements (see Engel, Hayes and Wang [2007]). The sample ends in 2011 so that there are five years in both the pre- and the post-event periods.
} 
We include control variables similar to those in the previous tests: industry gross profit margin (INDUSTRY_GPM), which is the industry average gross profit margin [(Item 1001 Item 1051)/Item 1001], and industry sales [Ln(INDUSTRY_SALES)], which is the logarithm of the average sales (Item 7240) of public firms in a particular industry. The U.K. sample to test Hypotheses 4 includes 17,217 firm-year observations in the U.K. and 80,922 firm-year observations in the United States between 2002 and 2011. Regression (7) summarizes the specification to test Hypothesis 4 using the U.K. sample:

$$
\begin{aligned}
& \text { CCC_ } 1 Q_{i}=\alpha+\beta_{1} U K_{i}+\beta_{2} U K Q T R_{t}+\boldsymbol{\beta}_{3} \boldsymbol{U K}_{\boldsymbol{i}} * \boldsymbol{U} \boldsymbol{K Q T R}_{\boldsymbol{t}}+\beta_{4} I N D U S T R Y_{-} G P M_{i t} \\
& +\beta_{5} \operatorname{Ln}(\text { INDUSTRY_SALES })_{i t}+\varepsilon_{i t} \\
& \text { CCC_1Q2Q } Q_{i}=\alpha+\beta_{1} U K_{i}+\beta_{2} U K Q T R_{t}+\boldsymbol{\beta}_{3} \boldsymbol{U K}_{\boldsymbol{i}} * \boldsymbol{U K Q T T R _ { \boldsymbol { t } }}+\beta_{4} I N D U S T R Y{ }_{-} G P M_{i t} \\
& +\beta_{5} \operatorname{Ln}\left(\text { INDUSTRY_SALES) }{ }_{i t}+\varepsilon_{i t}\right. \\
& \text { CCC_2 } Q_{i}=\alpha+\beta_{1} U K_{i}+\beta_{2} U K Q T R_{t}+\boldsymbol{\beta}_{3} \boldsymbol{U K}_{\boldsymbol{i}} * \boldsymbol{U K Q T T R _ { \boldsymbol { t } }}+\beta_{4} I N D U S T R Y_{-} G P M_{i t} \\
& +\beta_{5} \operatorname{Ln}(\text { INDUSTRY_SALES })_{i t}+\varepsilon_{i t}
\end{aligned}
$$

The variable of interest is the coefficient on the interaction term between UKQTR and UK, the indicator variable for U.K. firms. The coefficient captures the comparison between the changes in the distributions of public firms in each of the three groups formed based on the length of industry cash conversion cycles in the U.K. with the corresponding changes in the United States, that is, a difference-in-differences comparison. We expect $\beta_{3}$ to be negative when the dependent variable is $\mathrm{CCC}_{-} 1 \mathrm{Q} 2 \mathrm{Q}$.

\section{Empirical results}

\subsection{Results for test of Hypothesis 1}

Table 1 reports the mean and median abnormal research and development expenses (ARND) in firm-year observations in the year of seasoned equity offerings (SEOs) partitioned by cash conversion cycle and investor impatience (IMPATIENCE). Lower ARND indicates that the firm cuts research and development expenses in the year of SEOs, indicative of higher 
managerial myopia. As the first row of results shows, the mean and median ARND are -0.031 and -0.034 , respectively, for firms with cash conversion cycles longer than one quarter, and 0.006 and -0.003 , respectively, for firms with cash conversion cycles shorter than one quarter. The differences between the two groups are statistically significant $(t=-2.79$ and $z=-2.37)$. The evidence suggests that compared to firms with cash conversion cycles shorter than one quarter, firms with cash conversion cycles longer than one quarter cut more research and development expenses in the year of SEOs. The evidence supports Hypothesis 1a.

The next two rows of results in table 1 report the mean and median ARND in groups partitioned by investor impatience (IMPATIENCE). For firms with high investor impatience (IMPATIENCE $=1$ ) and cash conversion cycles longer than one quarter, the mean and median ARND in the year of SEOs are -0.048 and -0.045 , respectively. The corresponding numbers are 0.004 and -0.003 , respectively, for firms with high investor impatience and cash conversion cycles shorter than one quarter. The differences between the two groups are statistically significant $(t=-2.67$ and $z=-2.37)$. In contrast, the two groups of firms with low investor impatience (IMPATIENCE $=0$ ) show no significant differences in ARND in the year of SEOs. Specifically, the mean and median ARND are -0.012 and -0.010 , respectively, for firms with cash conversion cycles longer than one quarter, and 0.008 and 0.005 , respectively, for firms with cash conversion cycles shorter than one quarter. The $t$-statistic and $z$-statistic for differences in mean and median between the two groups are -1.10 and -0.84 , respectively. Finally, the last row of table 1 shows that the differences in ARND in the year of SEOs between firms with high investor impatience and firms with low investor impatience are statistically significant only when these firms' cash conversion cycles are longer than one quarter. These results support Hypothesis $1 \mathrm{~b}$ and indicate that the difference in managerial myopia between firms whose cash conversion 
cycles are longer than one quarter and firms whose cash conversion cycles are shorter than one quarter is more pronounced when investors are impatient.

Overall, the results in table 1 are consistent with the predictions in Gigler et al. [2014] that, in response to price pressure from the public market, disclosure frequency induced myopia is present only under the scenario of frequent reporting (that is, when the average length of cash payoffs from all projects is longer than the mandatory reporting frequency), and that disclosure frequency induced myopia increases as price pressure from the public market increases. These results validate the use of the cash conversion cycle as an empirical proxy for the average length of cash payoffs from all projects.

\subsection{Results for tests of Hypothesis 2}

Panel A of table 2 provides descriptive statistics on the 5,842 industry-year observations in the sample for testing Hypothesis 2. On average, $2.654 \%$ of firms in an industry are public firms. The average length of the cash conversion cycle is 100.99 days and the median length of the cash conversion cycle is 89.38 days, with one industry having a cash conversion cycle as short as 0.5 days and another having a cash conversion cycle as long as 4,070.63 days. The average number of firms in an industry, according to the Census of Manufactures, is about 733 firms, with one industry having only 8 firms and another having as many as 22,180 . The average industry-level gross profit margin is $8 \%$, whereas the median industry-level gross profit margin is $29 \%$. The average industry-level revenue is $\$ 1,835.48$ million and median industry-level sales are $\$ 547.20$ million.

Panel B of table 2 provides the correlation table. On the univariate basis, the Pearson and Spearman correlations between the length of cash conversion cycle (INDUSTRY_CCC) and the 
$\log$ odds of public firms (LOG_ODDS) are 0.033 and 0.062, respectively, and both are statistically significant at the $1 \%$ level. This is consistent with the notion that a longer cash conversion cycle is associated with a greater need to raise capital externally. The Pearson and Spearman correlations between LOG_ODDS and the number of firms in a given industry (NUM_FIRMS_CENSUS) are -0.496 and -0.596 , respectively, both of which are statistically significant at the $1 \%$ level. This is consistent with the finding in Ali et al. [2009] that, in industries with fewer firms, there is a greater percentage of large public firms; these firms are more likely to be included in Compustat.

Table 3 presents the results of Regression (3). In the first column, we include only the length of the cash conversion cycle and the number of firms as independent variables to explain the variation in the proportion of public firms across different industries. The two variables combined are able to explain $24.68 \%$ of variation in the proportion of public firms across different industries. The slope coefficient on NUM_FIRMS_CENSUS is -0.458 and statistically significant $(t=-6.38)$, consistent with prior findings that industries with fewer firms have a greater percentage of large public firms. The slope coefficient on INDUSTRY_CCC is statistically insignificant, suggesting no relation between the length of cash conversion cycles and the proportion of public firms when all lengths of cash conversion cycle are considered.

In the second column of table 3 , four control variables, including industry profitability (INDUSTRY_GPM), the logarithm of the industry average sales (Ln[INDUSTRY_SALES]), the indicator variable for the post-SFAS 131 regime (POST_SFAS131), and the indicator variable for the post-SOX regime (POST_SOX) are included to explain the variation in the proportion of public firms across industries. With the control variables, the explanatory power of the regression increases from $24.68 \%$ to $35.76 \%$. The slope coefficient on INDUSTRY_CCC is now 
positive and statistically significant $(t=3.13)$. Consistent with the expectation that firms in more profitable industries face greater proprietary costs of public disclosure, and thus have a greater incentive to avoid the commitment to mandatory disclosure, the slope coefficient on INDUSTRY_GPM is negative and statistically significant $(t=-4.89)$. The slope coefficient on Ln[INDUSTRY_SALES] is positive and statistically significant $(t=5.86)$, consistent with the bias that larger firms are more likely to be included in Compustat (see Ali et al. [2009]). The third column of table 3 adds one more independent variable, CCC_LONG1Q, the indicator for INDUSTRY_CCC longer than one quarter. The slope coefficient on CCC_LONG1Q is positive and statistically significant $(t=1.97)$, suggesting that firms in industries whose cash conversion cycles are longer than one quarter, on average, have a greater need for equity from the public market than firms in industries whose cash conversion cycles are shorter than one quarter.

Finally, the last column of table 3 presents the results on whether the association between the length of cash conversion cycles and the proportion of public firms is weakened in industries whose cash conversion cycles are longer than the frequency of mandatory reporting. The slope coefficient on the interaction term between INDUSTRY_CCC and CCC_LONG1Q is - 0.005 and statistically significant $(t=-2.48)$. The result indicates that, when the industry cash conversion cycle is longer than one quarter, the extra incentive to stay private to avoid disclosure frequency induced myopia triggers a downward kink in the relation between the proportion of public firms in that industry and the length of cash conversion cycle. The magnitude of the slope coefficients on INDUSTRY_CCC and CCC_LONG1Q*INDUSTRY_CCC implies that, when cash conversion cycles are shorter than one quarter, a one-day increase in the length of the cash conversion cycle is associated with a $0.6 \%$ increase in the odds of being a public firm, which is equivalent to a $0.016 \%$ increase in the proportion of public firms from the mean. In contrast, 
when cash conversion cycles are longer than one quarter, a one-day increase in the length of the cash conversion cycle is associated with only a $0.1 \%$ increase in the odds of being a public firm, which translates to a $0.003 \%$ increase in the proportion of public firms from the mean. In other words, a one-day increase in the cash conversion cycle in industries whose cash conversion cycles are longer than one quarter is associated with an additional $0.013 \%(0.016 \%-0.003 \%)$ decrease in the proportion of public firms from the mean, compared to the corresponding change in industries whose cash conversion cycles are shorter than one quarter. The evidence is consistent with the interpretation that disclosure frequency induced myopia is more pronounced when the industry's cash conversion cycle exceeds the frequency of mandatory reporting in the United States.

Table 4 presents results of Regression (4). In the first column, the slope coefficient on CCC_LONG1Q*INDUSTRY_DSI is -0.007 and statistically significant $(t=-3.58)$. In the next two columns, the slope coefficients on CCC_LONG1Q*INDUSTRY_DSO and CCC_LONG1Q*INDUSTRY_DPO are 0.001 and -0.002 , respectively, both of which are statistically insignificant. In the last column, when the three components of the cash conversion cycle are included simultaneously as explanatory variables, the slope coefficient on CCC_LONG1Q*INDUSTRY_DSI is -0.007 and statistically significant $(t=-2.01)$, and the coefficients on CCC_LONG1Q*INDUSTRY_DPO and CCC_LONG1Q*INDUSTRY_DSO remain statistically insignificant.

To summarize, the results in this section are consistent with the interpretation that disclosure frequency induced myopia is more pronounced when the length of the cash conversion cycle exceeds the frequency of mandatory reporting, which deters more firms in 
those industries from entering the public market and thereby provides strong support for Hypothesis 2.

\subsection{Results for tests of Hypothesis 3}

Panel A of table 5 reports the mean and median of the variables in the test of Hypothesis 3. The average cash conversion cycle is -22.79 days for the full sample of 8,120 firm-year observations from 2002 to 2006. In the subsample of 574 firm-year observations of U.K. domiciled firms that were listed on the U.S. exchanges, the average cash conversion cycle is -57.66 days, suggesting that these firms rely heavily on suppliers to finance their operations. The average industry-adjusted cash conversion cycle (CCC_DM1 and CCC_DM2) is negative for the subsample of firms domiciled in the U.K. but listed in the United States, suggesting that these

firms have shorter cash conversion cycles than their industry peers. The last two columns show that U.S.-listed U.K. firms have comparable ROA but are much bigger than their counterparts listed on the U.K. stock exchanges.

Panel B of table 5 reports the results of Regression (5). The coefficient on cash conversion cycle is -0.038 and statistically significant $(C h i$-square $=36.31)$, suggesting that U.K. firms with longer cash conversion cycles are less likely to list on U.S. stock exchanges, where quarterly reporting is required. The coefficients on CCC_DM1 and CCC_DM2 are both -0.029 and statistically significant, indicating that U.K. firms with cash conversion cycles longer than those of their industry peers are less likely to list on U.S. stock exchanges. In other words, these firms are more likely to list on U.K. exchanges that require less frequent mandatory disclosure to mitigate disclosure frequency induced myopia. The evidence supports Hypothesis 3. 


\subsection{Results for tests of Hypothesis 4}

\subsubsection{The U.S. sample}

Table 6 reports results of Regression (6). Focusing on the full-model results in the last column, we observe that the slope coefficient on the interaction term between CCC_1Q2Q and USQTR is -0.293 and statistically significant $(t=-2.36)$. The evidence suggests that the proportion of public firms in industries whose cash conversion cycles are longer than one quarter and shorter than two quarters decreased significantly after the mandatory reporting frequency changed from semi-annual to quarterly in the United States. The magnitude of the slope coefficients on USQTR and CCC_1Q2Q*USQTR implies that, for firms in industries whose cash conversion cycles are longer than one quarter and shorter than two quarters $\left(C_{C C} 1 \mathrm{Q} 2 \mathrm{Q}=\right.$ 1), the change of mandatory reporting frequency from semi-annual to quarterly is associated with a $2.3 \%$ decrease in the odds of being a public firm, which is equivalent to a $0.06 \%$ decrease in the proportion of public firms from the mean. In contrast, for firms in the remaining industries whose cash conversion cycles are either shorter than the new reporting frequency or longer than the old reporting frequency, the change in mandatory reporting frequency is associated with a $31 \%$ increase in the odds of being a public firm, which translates to a $0.804 \%$ increase in the proportion of public firms from the mean. In other words, for industries whose cash conversion cycles are longer than the new reporting frequency and shorter than the old reporting frequency, the change in the mandatory reporting frequency resulted in an additional $0.864 \%(0.804 \%+$ $0.060 \%$ ) decrease in the proportion of public firms from the mean, compared to the corresponding change in other industries. The evidence suggests that, in the United States, the change of mandatory disclosure frequency from semi-annual to quarterly decreases, to a greater 
extent than in other industries, the proportion of public firms in industries whose cash conversion cycles are between one quarter and two quarters.

\subsubsection{The UK sample}

Table 7 reports the percentage of firms in the three groups partitioned by industry median cash conversion cycle, measured using U.K. data between 2002 and 2006, when semi-annual reporting was required for U.K. public firms. The first three columns report results for U.K. firms. In the U.K., $83.5 \%$ of public firms are in industries whose median cash conversion cycles are less than one quarter during 2002 and 2006. The percentages are $16.3 \%$ and $0.2 \%$ for firms in industries with cash conversion cycles between one quarter and two quarters and those in industries with cash conversion cycles longer than two quarters, respectively. The corresponding percentages for the period between 2007 and 2011 are 84.6\%, 15.2\%, and $0.2 \%$, respectively. The changes between the two sample periods are significant except for the group of firms whose industry median cash conversion cycles are longer than two quarters. The finding suggests that, after U.K. public firms were required to make quarterly reports in 2007 , there was a significant change in industry composition. Industries whose median cash conversion cycles are between one quarter and two quarters ${ }^{10}$ have a much lower representation in U.K. public firms. In contrast, industries whose median cash conversion cycles are shorter than one quarter have a higher representation in U.K. public firms. In the corresponding periods, there was no significant change in the representation of industries whose median cash conversion cycles are longer than two quarters in U.K. public firms. This group is affected to a lesser extent by the increase in the mandatory reporting frequency.

\footnotetext{
${ }^{10}$ These industries include electrical, construction, textiles, drugs, cosmetics and health care, machinery and equipment, apparel, and aerospace.
} 
A potential reason for the decrease in the proportion of firms from industries whose cash conversion cycles are between one quarter and two quarters is their lesser economic importance. Therefore, we use the industry composition of public firms in the U.S. as a benchmark for economics-based industry composition. Interestingly, we find that in the United States there is no significant change in the distribution of public firms among the three groups, suggesting that these industries have not become less important economically.

The last column of Table 7 reports the difference-in-differences comparison. Compared to their U.S. counterparts, U.K. firms in industries whose cash conversion cycles are between one quarter and two quarters (shorter than one quarter) have a significantly lower (higher) representation in public markets after public firms were required to make quarterly reports. Figure 1 plots the changes in the percentage of firms in each industry in the U.K. and the United States after U.K. public firms were required to make quarterly reports in 2007. Panel A reports the change for each industry in the U.K. and the United States separately. Panel B reports the change of percentage for each industry in the U.K. minus that in the United States. As evident from Panel B, during the 2007-2011 sample period, there is a marked decrease in the percentage of firms in industries such as construction, textiles, drugs, cosmetics and health care, machinery and equipment, and apparel. All those industries had cash conversion cycles between one quarter and two quarters prior to the change in the frequency of mandatory disclosure.

Table 8 reports the results of Regression (7). The variable of interest is the coefficient on UK*UKQTR, the interaction term between the indicator variable for U.K. firms and the indicator variable for mandatory quarterly reporting. As the second column shows, the coefficient on UK*UKQTR is -0.307 and statistically significant (Chi-square $=41.83)$ when the dependent variable is CCC_1Q2Q, the indicator variable for industries whose cash conversion cycles are 
between one quarter and two quarters. The coefficient on UK*UKQTR is significantly positive $($ Chi-square $=38.84)$ when the dependent variable is CCC_1Q, the indicator variable for industries whose cash conversion cycles are shorter than one quarter, and is negative but statistically insignificant when the dependent variable is CCC_2Q, the indicator variable for industries whose cash conversion cycles are longer than two quarters. These results corroborate the findings in table 7 that industries with cash conversion cycles between one quarter and two quarters (shorter than one quarter) have a significantly lower (higher) representation in public markets after the U.K. adopted quarterly reporting.

In summary, the difference-in-differences results in table 7 and table 8 generally support the conclusion that, after controlling for common factors that affect firms entering or leaving a particular industry, there is a net outflow of U.K. firms from the public markets in industries whose cash conversion cycles are longer than one quarter but shorter than two quarters in response to the increase in the frequency of mandatory reporting. Taking together the results using the U.S. and the U.K. samples, we observe that an increase in the frequency of mandatory reporting deters more firms from entering the public markets to avoid disclosure frequency induced myopia, especially in industries whose cash conversion cycles are shorter than the old reporting interval but longer than the new reporting interval. These results support Hypothesis 4 .

\section{Conclusion}

This study provides new evidence on the economic consequences of the frequency of mandatory disclosure. We use the length of the cash conversion cycle as a proxy for the average length of cash payoffs from all projects and find that disclosure frequency induced myopia is present only when the cash conversion cycle is longer than the mandatory reporting interval and 
that disclosure frequency induced myopia increases as price pressure from the public market increases. With respect to the influence of mandatory reporting on the decision to go public, this study finds that the incentive to stay private to avoid disclosure frequency induced myopia creates a downward kink in the relation between the length of cash conversion cycles and the proportion of public firms around the time frame that corresponds to the mandatory reporting interval at the industry level. In addition, at the firm level, public firms with cash conversion cycles longer than those of industry peers are more likely to list on exchanges that require less frequent mandatory disclosure to minimize disclosure frequency induced myopia. Finally, when mandatory reporting frequency increased from semi-annual to quarterly, we observe a sharper decline in the percentage of public firms from industries whose cash conversion cycles are between one quarter and two quarters compared to those from other industries both in the United States and in the U.K.

The empirical results should be assessed with the caveat that this study adopts the assumption in Gigler et al. [2014] that there is no scope for informative accounting accruals. Therefore, one direction for future research would be to explore how accounting accruals might influence the relationship between the cash conversion cycle, disclosure frequency induced myopia, and the decision to be public. 


\section{References}

ALI, A., S. KLASA, and E. YEUNG. 'The Limitations of Industry Concentration Measures Constructed with Compustat Data: Implications for Finance Research.' Review of Financial Studies 22 (2009): 3839-71.

ALLAYANNIS, G., and J. IHRIG. 'Exposure and Markups.' Review of Financial Studies 14 (2001): 805-35.

BERGER, P., and R. HANN. 'The Impact of SFAS No. 131 on Information and Monitoring.' Journal of Accounting Research 41 (2003): 163-223.

BHOJRAJ, S., C. LEE, and D. OLER. 'What's My Line? A Comparison of Industry Classification Schemes for Capital Market Research.' Journal of Accounting Research 41 (2003): 745-74.

CAMPELlO, M. 'Debt Financing: Does It Hurt or Boost Firm Performance in Product Markets?' Journal of Financial Economics 82 (2006): 135-72.

CHEVALIER, J. 'Capital Structure and Product-Market Competition: Empirical Evidence from the Supermarket Industry.' American Economic Review 85 (1995): 415-35.

COFFEE, J. 'The Future as History: The Prospects for Global Convergence in Corporate Governance and Its Implications.' Northwestern University Law Review 93 (1999): 641-708.

COHEN, D., and P. ZAROWIN. 'Accrual-based and Real Earnings Management Activities around Seasoned Equity Offerings.' Journal of Accounting and Economics 50 (2010): 2-19.

DECHOW, P. 'Accounting Earnings and Cash Flows as Measures of Firm Performance: The Role of Accounting Accruals.' Journal of Accounting and Economics 18 (1994): 3-42.

DRAPER, N.R., and H. SMITH. Applied Regression Analysis. New York: Wiley, 1966.

ENGEL, E., R. HAYES, and X. WANG. 'The Sarbanes-Oxley Act and Firms' Going-private Decisions.' Journal of Accounting and Economics 44 (2007): 116-45.

ERNSTBERGER, J., B. LINK, M. STICH, and O. VOGLER. 'The Real Effects of Mandatory Quarterly Reporting.’ Accounting Review, forthcoming (2017).

EWERT, R., and A. WAGENHOFER. 'Economic Effects of Tightening Accounting Standards to Restrict Earnings Management.’ Accounting Review 80 (2005): 1101-24.

GIGLER, F., C. KANODIA, H. SAPRA, and R. VENUGOPALAN. 'How Frequent Financial Reporting Can Cause Managerial Short-Termism: An Analysis of the Costs and Benefits of Increasing Reporting Frequency.' Journal of Accounting Research 52 (2014): 357-87. 
HELLMAN, T., and M. PURI. 'The Interaction between Product Market and Financing Strategy: The Role of Venture Capital.' Review of Financial Studies 13 (2000): 959-84.

KAROLYI, A. 'Corporate Governance, Agency Problems and International Cross-listings: A Defense of the Bonding Hypothesis.' Emerging Markets Review 13 (2012): 516-47.

ROYCHOWDHURY, S. 'Earnings Management through Real Activities Manipulation.' Journal of Accounting and Economics 42 (2006): 335-70.

STEIN, J. 'Efficient Capital Markets, Inefficient Firms: A Model of Myopic Corporate Behavior.' Quarterly Journal of Economics 104 (1989): 655-69.

UPBIN, B. The Six Habits of Successful Private Companies. Forbes, 2013. http://www.forbes.com/sites/bruceupbin/2013/06/30/the-six-habits-of-successful-privatecompanies $/ 2 /$.

ZANG, A.Y. 'Evidence on the Trade-off between Real Activities Manipulation and Accrualbased Earnings Management.' Accounting Review 87 (2012): 675-703. 
Figure 1 Change in industry distributions among U.K. and U.S. firms after U.K. firms are required to make quarterly reports

Panel A: By percentage of firms in each industry

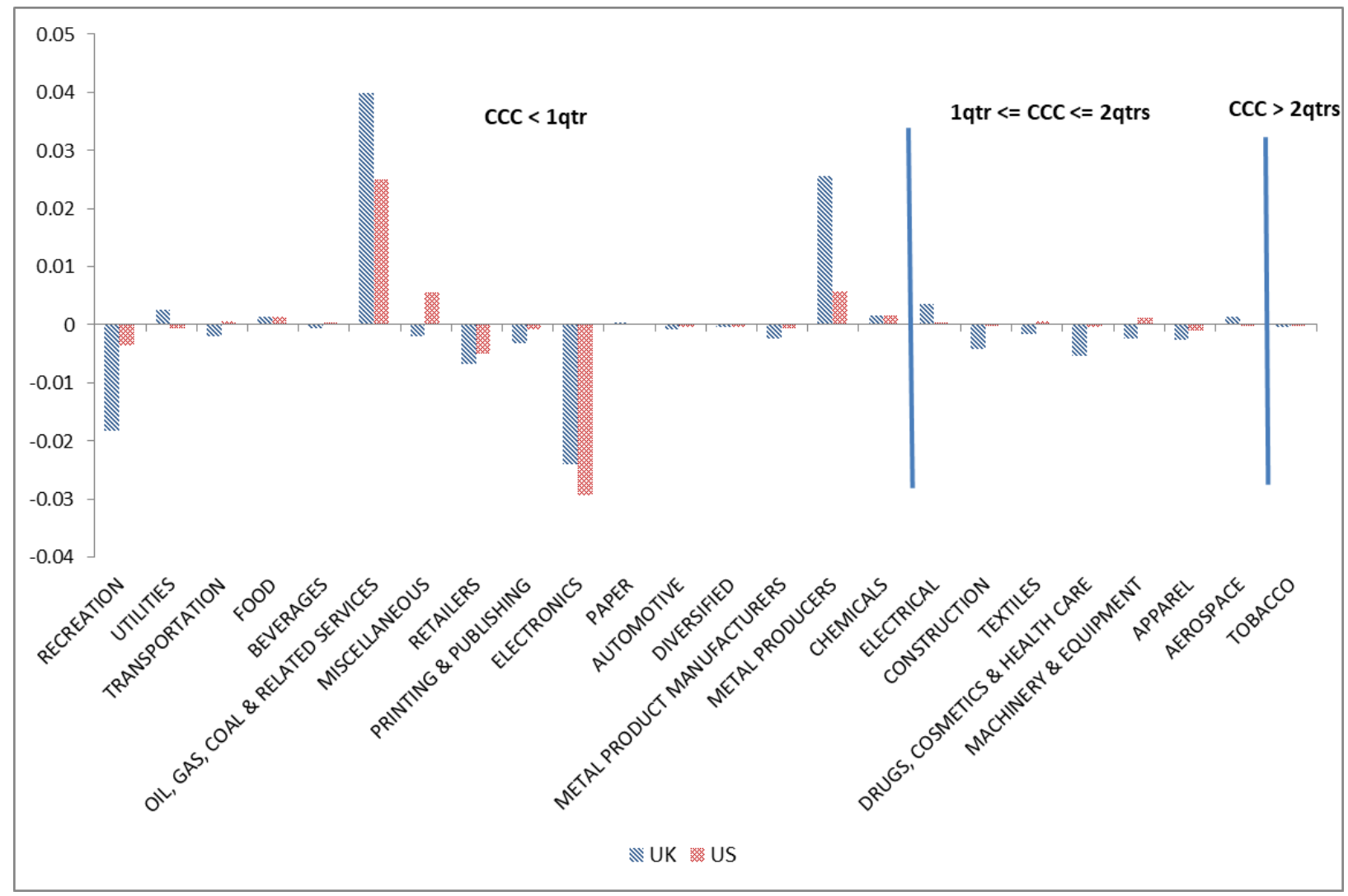




\section{Figure 1 \\ (continued)}

Panel B: Differences in the changes in the percentage of firms in each industry between the U.K. and the United States

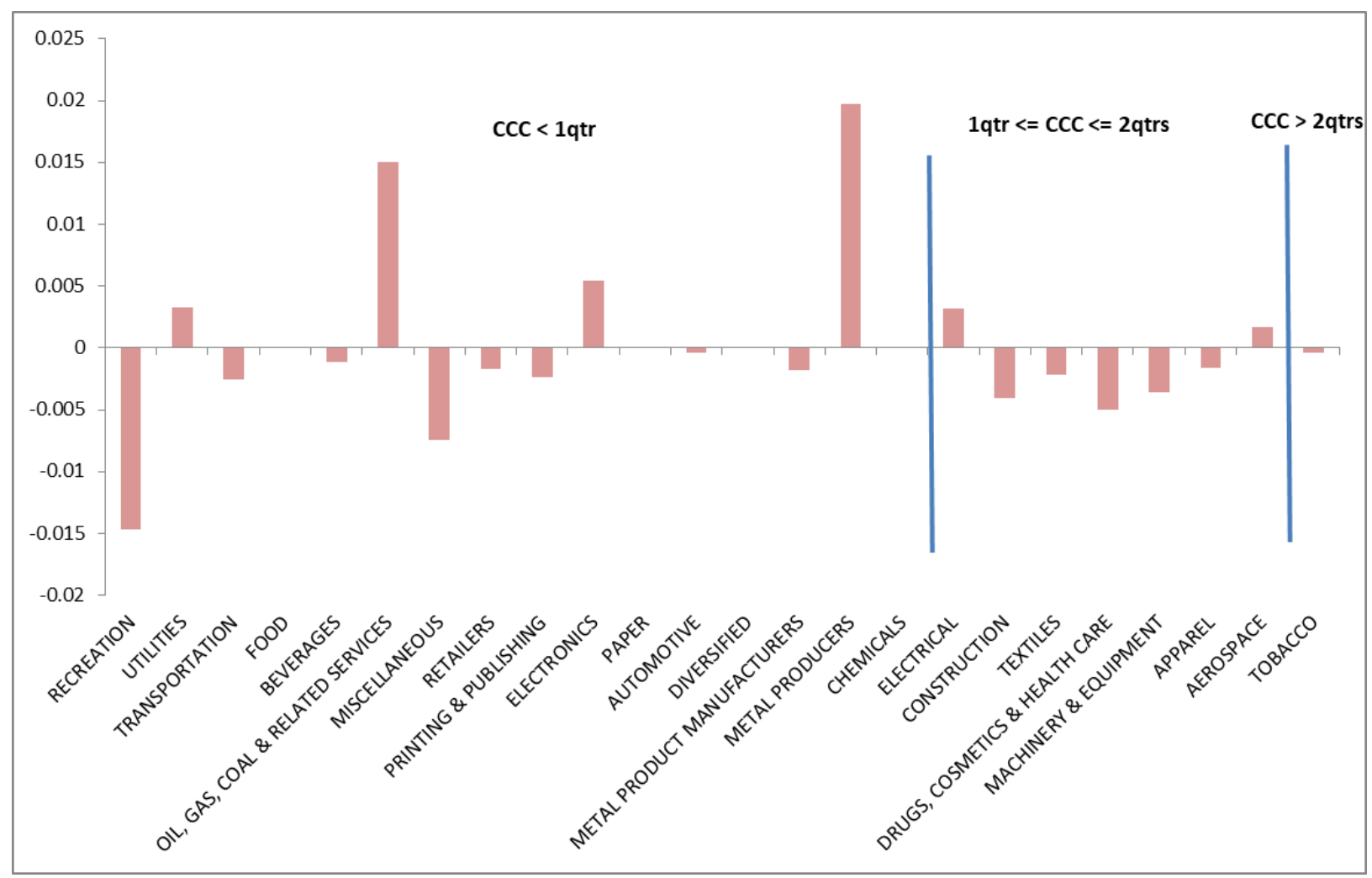

Note: $\mathrm{CCC}=$ cash conversion cycle.

Panel A plots the changes in the percentage of firms in each industry in the U.K. and the United States after U.K. firms were required to make quarterly reports in 2007. The changes are calculated between two periods: $2002-06$ and 2007-11. Industry median cash conversion cycle is measured using all U.K. observations in Worldscope between 2002 and 2006 when semi-annual reporting was required. Cash conversion cycle is calculated as days' sales outstanding (accounts receivable divided by daily sales) plus days' sales in inventory (inventory divided by daily cost of goods sold) minus days' sales in payables (accounts payable divided by daily cost of goods sold). Industries are defined by the two-digit industry group (Item 6011) in Worldscope. Financial industries (Item 6011 between 4310 and 4395) are excluded. Panel B plots the differences in changes in the percentage of firms in each industry between the U.K. and the United States after U.K. firms were required to make quarterly reports in 2007. 
Table 1

Abnormal Research and Development Expenses in Groups Partitioned by Cash Conversion Cycle and Investor Impatience

\begin{tabular}{|c|c|c|c|c|c|c|c|c|}
\hline & \multicolumn{3}{|c|}{ CCC $>1$ quarter } & \multicolumn{3}{|c|}{$\mathrm{CCC}<=1$ quarter } & \multicolumn{2}{|c|}{$\mathrm{CCC}>1$ quarter $-\mathbf{C C C}<=1$ quarter } \\
\hline & $\mathbf{N}$ & Mean & Median & $\mathbf{N}$ & Mean & Median & Mean & Median \\
\hline Full sample & 130 & -0.031 & -0.034 & 239 & 0.006 & -0.003 & $\begin{array}{c}-0.037 * * * \\
(-2.79)\end{array}$ & $\begin{array}{c}-0.031 * * \\
(-2.37)\end{array}$ \\
\hline IMPATIENCE $=1$ & 68 & -0.048 & -0.045 & 118 & 0.004 & -0.003 & $\begin{array}{c}-0.052 * * * * \\
(-2.67) \\
\end{array}$ & $\begin{array}{c}-0.042 * * \\
(-2.44) \\
\end{array}$ \\
\hline IMPATIENCE $=0$ & 62 & -0.012 & -0.010 & 121 & 0.008 & 0.005 & $\begin{array}{l}-0.020 \\
(-1.10)\end{array}$ & $\begin{array}{l}-0.015 \\
(-0.84)\end{array}$ \\
\hline $\begin{array}{l}\text { "IMPATIENCE=1" - } \\
\text { "IMPATIENCE=0" }\end{array}$ & & $\begin{array}{c}-0.036 * * * \\
(-2.54)\end{array}$ & $\begin{array}{c}-0.035 * * \\
(-2.23)\end{array}$ & & $\begin{array}{l}-0.004 \\
(-0.31)\end{array}$ & $\begin{array}{l}-0.008 \\
(-0.54)\end{array}$ & & \\
\hline
\end{tabular}

This table reports the mean and median abnormal research and development expenses in the year of seasoned equity offerings partitioned by cash conversion cycle and investor impatience (IMPATIENCE). Abnormal research and development expense is the residual from the following regression: $\frac{R N D_{t}}{\text { ASSETS }_{t-1}}=\alpha_{0}+$ $\alpha_{1} \frac{1}{\text { ASSETS }_{t-1}}+\alpha_{2} \frac{\text { SALES }_{t-1}}{\text { ASSETS }_{t-1}}+\varepsilon_{t}$, where RND $\mathrm{R}_{\mathrm{t}}$ is research and development expense in year $t$. SALES $\mathrm{t}_{\mathrm{t}-1}$ and ASSETS $\mathrm{t}_{\mathrm{t}-1}$ are sales and total assets, respectively, in year $t-1$. The regression is estimated cross-sectionally by industry and year for the period from 1987 to 2015 . We require that there be at least eight observations for every industry and year combination. Industries are defined by six-digit NAICS code. Financial firms (those for which the first two digits of the NAICS codes are 52 and 53) are excluded. Cash conversion cycle is calculated from Compustat as days' sales outstanding (accounts receivable divided by daily sales) plus days' sales in inventory (inventory divided by daily cost of goods sold) minus days' sales in payables (accounts payable divided by daily cost of goods sold). We take the median cash conversion cycle over the previous five years to proxy for the normal level of cash conversion cycle for each firm-year. To measure IMPATIENCE, we estimate the following regression for each firm-year using past five years of data: $R E T_{t}=\beta_{0}+\beta_{1} \frac{C F O_{q 1}}{\text {ASSETS }_{t-1}}+\beta_{2} \frac{C_{2 F O_{q 2}-q 4}}{\text { ASSETS }_{t-1}}+\beta_{3} \frac{C F O_{t+1}}{\text { ASSETS }_{t-1}}+$ $\mu_{t}$, where $\mathrm{RET}_{\mathrm{t}}$ is the buy-hold return over the 12-month period starting four months after the end of fiscal year $t-1 ; \mathrm{CFO}_{\mathrm{q} 1}, \mathrm{CFO}_{\mathrm{q} 2-\mathrm{q} 4}$, and $\mathrm{CFO}$ standardized cash flow from operations of the first quarter of year $t$, the second quarter to the fourth quarter of year $t$, and year $t+1$, respectively. IMPATIENCE equals one if the ratio $a b s(\beta 1) /(a b s(\beta 2)+a b s(\beta 3))$ is above the industry median, and zero otherwise. The seasoned equity offering sample is retrieved from the Thomson Reuters SDC New Issue database for the period from 1987 to 2015. The sample is restricted to firms listed on the New York Stock Exchange, the American Stock Exchange and NASDAQ and excludes initial public offerings, private placements, right issues, spin-offs, and unit issues. $T$-statistics and Wilcoxon z-statistics for the differences in mean and median are reported in the parentheses. $* * *, * *, *$ denote statistical significance at $0.01,0.05$, and 0.10 levels, respectively, using a two-tailed test. 
Table 2

Summary Statistics on Cash Conversion Cycles and Industry Characteristics

Panel A: Descriptive statistics

\begin{tabular}{|l|c|c|c|c|}
\hline & NUM_FIRMS_CENSUS & PROPORTION & INDUSTRY_CCC & INDUSTRY_GPM \\
\hline N & 5,842 & 5,842 & 5,842 & 5,842 \\
\hline Mean & 733 & 2.654 & 100.99 & 0.08 \\
\hline Median & 343 & 1.087 & 89.38 & 0.29 \\
\hline Std & 1,551 & 4.723 & 82.29 & 1.19 \\
\hline Min & 8 & 0.005 & 0.50 & -18.92 \\
\hline Max & 22,180 & 90.343 & $4,070.63$ & 0.01 \\
\hline
\end{tabular}

Panel B: Pearson (above diagonal) and Spearman (below diagonal) correlations

\begin{tabular}{|c|c|c|c|c|c|c|c|}
\hline & LOG_ODDS & $\begin{array}{c}\text { INDUSTRY } \\
\text { _CCC }\end{array}$ & $\begin{array}{c}\text { NUM_FIRMS } \\
\text { _CENSUS }\end{array}$ & $\begin{array}{c}\text { INDUSTRY } \\
\text { _GPM }\end{array}$ & $\begin{array}{c}\text { INDUSTRY } \\
\text { _SALES }\end{array}$ & POST_SFAS131 & POST_SOX \\
\hline LOG_ODDS & & $0.033 * * *$ & $-0.496 * * *$ & $-0.170 * * *$ & $0.176^{* * *}$ & $-0.053 * * *$ & $-0.092 * * *$ \\
\hline INDUSTRY_CCC & $0.062 * * *$ & & -0.019 & 0.009 & $-0.094 * * *$ & $-0.034 * * *$ & $-0.076 * * *$ \\
\hline NUM_FIRMS_CENSUS & $-0.596^{* * *}$ & $0.044 * * *$ & & $0.025 *$ & $-0.071 * * *$ & 0.009 & 0.012 \\
\hline INDUSTRY_GPM & $-0.158 * * *$ & $0.199 * * *$ & $0.037 * * *$ & & 0.014 & $-0.048 * * *$ & $-0.062 * * *$ \\
\hline INDUSTRY_SALES & $0.287 * * *$ & $-0.240 * * *$ & $-0.137 * * *$ & $-0.068 * * *$ & & $0.062 * * *$ & $0.110 * * *$ \\
\hline POST_SFAS131 & $-0.050 * * *$ & $-0.066^{* * *}$ & $0.023^{*}$ & $-0.024 *$ & $0.160 * * *$ & & $0.448 * * *$ \\
\hline POST_SOX & $-0.086^{* * *}$ & $-0.117 * * *$ & $0.038 * * *$ & $-0.024 *$ & $0.241 * * *$ & $0.448 * * *$ & \\
\hline
\end{tabular}




\section{Table 2}

\section{(continued)}

Industries are defined by six-digit NAICS code. NUM_FIRMS_CENSUS ${ }_{i t}$ is the number of all firms, both private and public, obtained from the Census of Manufactures. As U.S. Census of Manufactures takes place every five years, we use the census data from a given year, not only for that year, but also for the two years immediately before and after it. The proportion of public firms (PROPORTION $\mathrm{it}_{\mathrm{it}}$ ) is the percentage of public firms (obtained from Compustat) relative to NUM_FIRMS_CENSUS it $_{\text {it }}$ for a given industry-year. The log odds of the proportion of public firms (LOG_ODDS ${ }_{\text {it }}$ ) is measured as Ln[PROPORTION ${ }_{\mathrm{it}} /$ $\left.\left(1-P R O P O R T I O N_{i t}\right)\right]$. INDUSTRY_CCC ${ }_{i t}$ is the median length of the cash conversion cycles of public firms in year $t$ for a given industry, where cash conversion cycle is calculated from Compustat as days' sales outstanding (accounts receivable divided by daily sales) plus days' sales in inventory (inventory divided by daily cost of goods sold) minus days' sales in payables (accounts payable divided by daily cost of goods sold). INDUSTRY_GPM ${ }_{\text {it }}$ is the average gross profit margin of public firms in year $t$ for a given industry. INDUSTRY_SALES $\mathrm{it}_{\mathrm{t}}$ is the average sales (in US\$ millions) of public firms in year $t$ for a given industry. POST_SFAS131 $1_{t}$ is an indicator variable, which equals one if the year is 1997 or later, and zero otherwise. POST_SOX $\mathrm{t}$ is an indicator variable, which equals one if the year is 2002 or later, and zero otherwise. ${ }^{* * *},{ }^{* *}$, and ${ }^{*}$ denote statistical significance at $0.01,0.05$, and 0.10 levels, respectively, using a two-tailed test. 
Table 3

Regression Results on the Proportion of Public Firms and the Length of Cash Conversion Cycles

\begin{tabular}{|c|c|c|c|c|}
\hline \multirow{2}{*}{$\begin{array}{l}\text { Explanatory Variables } \\
\text { INTERCEPT }\end{array}$} & \multicolumn{4}{|c|}{$\begin{array}{c}\text { Dependent Variable } \\
=\text { Ln }[(\text { PROPORTION } /(1-\text { PROPORTION })]\end{array}$} \\
\hline & $\begin{array}{c}-4.208 * * * \\
(-31.91) \\
\end{array}$ & $\begin{array}{c}-5.441 * * * \\
(-26.26)\end{array}$ & $\begin{array}{c}-5.505 * * * \\
(-23.66) \\
\end{array}$ & $\begin{array}{c}-5.806 * * * \\
(-17.41)\end{array}$ \\
\hline INDUSTRY_CCC & $\begin{array}{l}0.000 \\
(1.06) \\
\end{array}$ & $\begin{array}{c}0.001 * * * \\
(3.13)\end{array}$ & $\begin{array}{c}0.001 * * * \\
(2.66)\end{array}$ & $\begin{array}{r}0.006^{*} \\
(1.93) \\
\end{array}$ \\
\hline CCC_LONG1Q & & & $\begin{array}{c}0.145 * * \\
(1.97) \\
\end{array}$ & $\begin{array}{c}0.469 * * \\
(2.16) \\
\end{array}$ \\
\hline CCC_LONG1Q*INDUSTRY_CCC & & & & $\begin{array}{c}-0.005 * * \\
(-2.48) \\
\end{array}$ \\
\hline NUM_FIRMS_CENSUS & $\begin{array}{c}-0.458 * * * \\
(-6.38) \\
\end{array}$ & $\begin{array}{c}-0.426 * * * \\
(-6.31)\end{array}$ & $\begin{array}{c}-0.424 * * * \\
(-6.35) \\
\end{array}$ & $\begin{array}{c}-0.425 * * * \\
(-6.32)\end{array}$ \\
\hline Ln(INDUSTRY_SALES) & & $\begin{array}{c}0.246 * * * \\
(5.86)\end{array}$ & $\begin{array}{c}0.251 * * * \\
(5.74)\end{array}$ & $\begin{array}{c}0.251 * * * \\
(5.65)\end{array}$ \\
\hline INDUSTRY_GPM & & $\begin{array}{c}-0.217 * * * \\
(-4.89)\end{array}$ & $\begin{array}{c}-0.216 * * * \\
(-5.04)\end{array}$ & $\begin{array}{c}-0.215^{* * * *} \\
(-5.08)\end{array}$ \\
\hline POST_SFAS131 & & $\begin{array}{c}-0.154 * * * \\
(-5.67)\end{array}$ & $\begin{array}{c}-0.153 * * * \\
(-5.94)\end{array}$ & $\begin{array}{c}-0.150 * * * \\
(-6.62)\end{array}$ \\
\hline POST_SOX & & $\begin{array}{c}-0.402 * * * \\
(-3.48)\end{array}$ & $\begin{array}{c}-0.397 * * * \\
(-3.42)\end{array}$ & $\begin{array}{c}-0.394 * * * \\
(-3.42)\end{array}$ \\
\hline Adjusted $R$-squared & $24.68 \%$ & $35.76 \%$ & $35.94 \%$ & $36.15 \%$ \\
\hline $\mathrm{N}$ & 5,842 & 5,842 & 5,842 & 5,842 \\
\hline
\end{tabular}


Table 3

(continued)

This table presents the regression results from Regression (3):

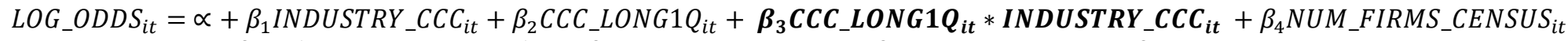

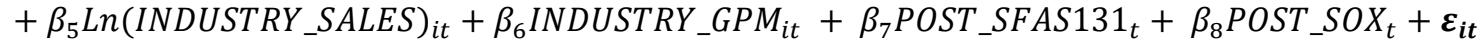

Industries are defined by six-digit NAICS code. NUM_FIRMS_CENSUS ${ }_{i t}$ is the number of all firms (in thousands), both private and public, obtained from the Census of Manufactures. As U.S. Census of Manufactures takes place every five years, we use the census data from a given year, not only for that year, but also for the two years immediately before and after it. The proportion of public firms (PROPORTION ${ }_{\text {it }}$ ) is the percentage of public firms (obtained from Compustat)

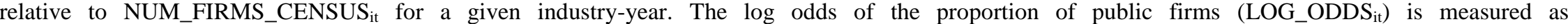
$\operatorname{Ln}\left[\right.$ PROPORTION $_{\mathrm{it}} /\left(\right.$ (1-PROPORTION $\left._{\mathrm{it}}\right)$ ]. INDUSTRY_CCC $\mathrm{it}_{\mathrm{it}}$ is the median length of the cash conversion cycles of public firms in year $t$ for a given industry, where cash conversion cycle is calculated from Compustat as days' sales outstanding (accounts receivable divided by daily sales) plus days' sales in inventory (inventory divided by daily cost of goods sold) minus days' sales in payables (accounts payable divided by daily cost of goods sold). CCC_LONG1Q it is an indicator variable for long cash conversion cycle, which equals one if INDUSTRY_CCC is longer than one quarter, and zero otherwise. INDUSTRY_GPM $\mathrm{it}_{\mathrm{it}}$ is the average gross profit margin of public firms in year $t$ for a given industry. Ln(INDUSTRY_SALES $\mathrm{it}_{\mathrm{it}}$ ) is the logarithm of the average sales (in US\$ millions) of public firms in year $t$ for a given industry. POST_SFAS131 $1_{\mathrm{t}}$ is an indicator variable, which equals one if the year is 1997 or later, and zero otherwise. POST_SOX $\mathrm{X}_{\mathrm{t}}$ is an indicator variable, which equals one if the year is 2002 or later, and zero otherwise. The $t$-statistics (in parentheses) are adjusted for two-way cluster-robust standard errors (clustered by industry and census year). ${ }^{* * *}, * *$, and ${ }^{*}$ denote statistical significance at $0.01,0.05$, and 0.10 levels, respectively, using a two-tailed test. 
Table 4

Regression Results on the Proportion of Public Firms and Components of Cash Conversion Cycles

\begin{tabular}{|c|c|c|c|c|}
\hline \multirow{2}{*}{$\begin{array}{l}\text { Explanatory Variables } \\
\text { INTERCEPT }\end{array}$} & \multicolumn{4}{|c|}{$\begin{array}{c}\text { Dependent Variable } \\
=\text { Ln }[(\text { PROPORTION } /(1-\text { PROPORTION })]\end{array}$} \\
\hline & $\begin{array}{c}-5.938 * * * \\
(-19.30)\end{array}$ & $\begin{array}{c}-5.597 * * * \\
(-24.81) \\
\end{array}$ & $\begin{array}{c}-5.811 * * * \\
(-29.11) \\
\end{array}$ & $\begin{array}{c}-6.039 * * * \\
(-20.63) \\
\end{array}$ \\
\hline CCC_LONG1Q & $\begin{array}{c}0.588 * * * \\
(3.65)\end{array}$ & $\begin{array}{l}0.091 \\
(0.48)\end{array}$ & $\begin{array}{c}0.281 * * \\
(2.52)\end{array}$ & $\begin{array}{c}0.398 * * \\
(2.08)\end{array}$ \\
\hline INDUSTRY_DSI & $\begin{array}{c}0.008 * * * \\
(3.74)\end{array}$ & & & $\begin{array}{c}0.007 * \\
(1.93) \\
\end{array}$ \\
\hline CCC_LONG1Q*INDUSTRY_DSI & $\begin{array}{c}-0.007 * * * \\
(-3.58)\end{array}$ & & & $\begin{array}{c}-0.007 * * \\
(-2.01)\end{array}$ \\
\hline INDUSTRY_DSO & & $\begin{array}{l}0.003 \\
(0.76)\end{array}$ & & $\begin{array}{l}0.001 \\
(0.29) \\
\end{array}$ \\
\hline CCC_LONG1Q*INDUSTRY_DSO & & $\begin{array}{l}0.001 \\
(0.20)\end{array}$ & & $\begin{array}{l}0.001 \\
(0.36)\end{array}$ \\
\hline INDUSTRY_DPO & & & $\begin{array}{c}0.008 * * \\
(2.39)\end{array}$ & $\begin{array}{l}0.003 \\
(0.67)\end{array}$ \\
\hline CCC_LONG1Q*INDUSTRY_DPO & & & $\begin{array}{l}-0.002 \\
(-1.06) \\
\end{array}$ & $\begin{array}{l}0.001 \\
(0.32) \\
\end{array}$ \\
\hline NUM_FIRMS_CENSUS & $\begin{array}{c}-0.420 * * * \\
(-6.32)\end{array}$ & $\begin{array}{c}-0.428 * * * \\
(-6.66)\end{array}$ & $\begin{array}{c}-0.421 * * * \\
(-6.31)\end{array}$ & $\begin{array}{c}-0.423 * * * \\
(-6.55)\end{array}$ \\
\hline Ln(INDUSTRY_SALES) & $\begin{array}{c}0.255^{* * *} \\
(5.69)\end{array}$ & $\begin{array}{c}0.251 * * * \\
(5.50)\end{array}$ & $\begin{array}{c}0.256 * * * \\
(6.02)\end{array}$ & $\begin{array}{c}0.258 * * * \\
(5.49)\end{array}$ \\
\hline INDUSTRY_GPM & $\begin{array}{c}-0.220 * * * \\
(-5.25)\end{array}$ & $\begin{array}{c}-0.219 * * * \\
(-5.48)\end{array}$ & $\begin{array}{c}-0.209 * * * \\
(-4.91)\end{array}$ & $\begin{array}{c}-0.219 * * * \\
(-5.38)\end{array}$ \\
\hline POST_SFAS131 & $\begin{array}{c}-0.158 * * * \\
(-5.27)\end{array}$ & $\begin{array}{c}-0.150 * * * \\
(-6.55)\end{array}$ & $\begin{array}{c}-0.159 * * * \\
(-5.70)\end{array}$ & $\begin{array}{c}-0.157 * * * \\
(-6.18)\end{array}$ \\
\hline POST_SOX & $\begin{array}{c}-0.396 * * * \\
(-3.40)\end{array}$ & $\begin{array}{c}-0.400 * * * \\
(-3.52)\end{array}$ & $\begin{array}{c}-0.406 * * * \\
(-3.41)\end{array}$ & $\begin{array}{c}-0.405 * * * \\
(-3.50)\end{array}$ \\
\hline Adjusted $R$-squared & $36.85 \%$ & $36.23 \%$ & $36.87 \%$ & $37.43 \%$ \\
\hline $\mathrm{N}$ & 5,842 & 5,842 & 5,842 & 5,842 \\
\hline
\end{tabular}




\section{Table 4 \\ (continued)}

This table presents the regression results from Regression (4):

$$
\begin{aligned}
& \text { LOG_ODDS }_{i t}=\propto+\beta_{1} C C C_{-} L O N G 1 Q_{i t}+\beta_{2} I N D U S T R Y \_D S I_{i t}+\beta_{3} \text { CCC_LONG1Q }_{i t} * \text { INDUSTRY_DSI } I_{i t}+\beta_{4} I N D U S T R Y \_D S O_{i t} \\
& +\beta_{5} \text { CCC_LONG1Q } \text { it }_{*} * \text { INDUSTRY_DSO } i t+\beta_{6} I N D U S T R Y_{-} D P O_{i t}+\beta_{7} \text { CCC_LONG1Q } \boldsymbol{Q}_{i t} * \text { INDUSTRY_DPO }{ }_{i t} \\
& \left.+\beta_{8} N U M_{-} \text {FIRMS_CENSUS } i t+\beta_{9} \text { Ln(INDUSTRY_SALES }\right)_{i t}+\beta_{10} I N D U S T R Y \_G P M_{i t}+\beta_{11} \text { POST_SFAS131 } 1_{t}+\beta_{12} P O S T \_S O X_{t}+\varepsilon_{i t}
\end{aligned}
$$

Industries are defined by six-digit NAICS code. NUM_FIRMS_CENSUS ${ }_{i t}$ is the number of all firms (in thousands), both private and public, obtained from the Census of Manufactures. As U.S. Census of Manufactures takes place every five years, we use the census data from a given year, not only for that year, but also for the two years immediately before and after it. The proportion of public firms (PROPORTION ${ }_{i t}$ ) is the percentage of public firms (obtained from Compustat) relative to NUM_FIRMS_CENSUS it $_{\text {it }}$ for a given industry-year. The $\log$ odds of the proportion of public firms (LOG_ODDS it $_{\text {) }}$ is measured as $\left.\mathrm{Ln}_{\text {PROPORTION }} \mathrm{it}_{\mathrm{it}} /(1-\mathrm{PROPORTION} \mathrm{it})\right]$. INDUSTRY_DSI $\mathrm{it}_{\mathrm{t}}$ is the median days' sales in inventory of public firms in year $t$ for a given industry, which is calculated as inventory divided by daily cost of goods sold. INDUSTRY_DSO ${ }_{\text {it }}$ is the median days' sales outstanding in accounts receivable of public firms in year $t$ for a given industry, which is calculated as accounts receivable divided by daily sales. INDUSTRY_DPO ${ }_{i t}$ is the median days' sales in accounts payable of public firms in year $t$ for a given industry, which is calculated as accounts payable divided by daily cost of goods sold. INDUSTRY_CCC it $_{\text {it }}$ the median length of the cash conversion cycles of public firms in year $t$ for a given industry, which is calculated as days' sales outstanding plus days' sales in inventory minus days' sales in payables. CCC LONG1Q ${ }_{i t}$ is an indicator variable for long cash conversion cycle, which equals one if INDUSTRY_CCC is longer than one quarter, and zero otherwise. INDUSTRY_GPM ${ }_{i t}$ is the average gross profit margin of public firms in year $t$ for a given industry. Ln(INDUSTRY_SALES ${ }_{i t}$ ) is the logarithm of the average sales (in US\$ millions) of public firms in year $t$ for a given industry. POST_SFAS131 $1_{\mathrm{t}}$ is an indicator variable, which equals one if the year is 1997 or later, and zero otherwise. POST_SOX $\mathrm{t}_{\mathrm{t}}$ is an indicator variable, which equals one if the year is 2002 or later, and zero otherwise. The $t$-statistics (in parentheses) are adjusted for two-way cluster-robust standard errors (clustered by industry and census year). ${ }^{* * *},{ }^{* *}$, and ${ }^{*}$ denote statistical significance at $0.01,0.05$, and 0.10 levels, respectively, using a two-tailed test. 
Table 5

Length of Cash Conversion Cycle and Listing Markets for U.K. Firms

Panel A: Descriptive statistics

\begin{tabular}{|c|c|c|c|c|c|c|}
\hline & & $\mathrm{CCC}$ & CCC_DM1 & CCC_DM2 & ROA & SALES \\
\hline \multirow{2}{*}{$\begin{array}{l}\text { Full Sample } \\
(\mathrm{N}=\mathbf{8 , 1 2 0})\end{array}$} & Mean & -22.79 & -1.91 & 0.00 & -0.08 & $1,334.15$ \\
\hline & Median & 44.34 & 61.80 & 65.32 & 0.05 & 66.09 \\
\hline \multirow{2}{*}{$\begin{array}{l}\text { USLIST=1 } \\
(\mathrm{N}=574)\end{array}$} & Mean & -57.66 & -27.06 & -25.40 & -0.08 & $6,591.98$ \\
\hline & Median & 47.31 & 57.00 & 58.00 & 0.07 & $2,872.99$ \\
\hline \multirow{2}{*}{$\begin{array}{l}\text { USLIST }=0 \\
(\mathbf{N}=7,546)\end{array}$} & Mean & -20.14 & 0.00 & 1.93 & -0.08 & 934.20 \\
\hline & Median & 43.94 & 62.10 & 66.00 & 0.05 & 55.31 \\
\hline \multirow{4}{*}{$\begin{array}{l}\text { USLIST }=1- \\
\text { USLIST }=0\end{array}$} & Mean & -37.52 & -27.06 & -27.33 & 0.01 & $5,657.78 * * *$ \\
\hline & & $(-1.23)$ & $(-0.90)$ & $(-0.91)$ & $(0.09)$ & $(14.88)$ \\
\hline & Median & 3.37 & -5.10 & -7.99 & $0.02 * * *$ & $2,817.68 * * *$ \\
\hline & & $(0.81)$ & $(-0.30)$ & $(-0.66)$ & (6.64) & $(24.54)$ \\
\hline
\end{tabular}

Panel B: Logistic regressions

\begin{tabular}{|c|c|c|c|}
\hline \multirow[b]{2}{*}{ Intercept } & \multicolumn{3}{|c|}{ Dependent Variable: USLIST } \\
\hline & $\begin{array}{l}-5.556^{* * * *} \\
(1,334.78)\end{array}$ & $\begin{array}{l}-5.508 * * * \\
(1,331.85)\end{array}$ & $\begin{array}{l}-5.506^{* * * *} \\
(1,332.01)\end{array}$ \\
\hline $\mathrm{CCC}$ & $\begin{array}{c}-\mathbf{0 . 0 3 8} * * * \\
(36.31) \\
\end{array}$ & & \\
\hline CCC_DM1 & & $\begin{array}{c}-0.029 * * * \\
(16.78) \\
\end{array}$ & \\
\hline CCC_DM2 & & & $\begin{array}{c}-0.029 * * * \\
(16.48) \\
\end{array}$ \\
\hline ROA & $\begin{array}{c}-0.311 * * * \\
(34.15)\end{array}$ & $\begin{array}{c}-0.316^{* * * *} \\
(33.47)\end{array}$ & $\begin{array}{c}-0.316^{* * *} \\
(33.46)\end{array}$ \\
\hline Ln (SALES) & $\begin{array}{c}0.523 * * * \\
(606.79) \\
\end{array}$ & $\begin{array}{c}0.516^{* * * *} \\
(598.28) \\
\end{array}$ & $\begin{array}{c}0.516^{* * *} \\
(598.18)\end{array}$ \\
\hline $\mathrm{N}$ & 8,120 & 8,120 & 8,120 \\
\hline
\end{tabular}




\section{Table 5}

\section{(continued)}

Panel B presents the logistic regression results from Regression (5):

$$
\begin{aligned}
& U_{S L I S T} T_{i t}=\alpha+\boldsymbol{\beta}_{1} \boldsymbol{C C C}_{i t}+\beta_{2} R O A_{i t}+\beta_{3} \operatorname{Ln}(S A L E S)_{i t}+\varepsilon_{i t} \\
& \text { USLIST }_{i t}=\alpha+\boldsymbol{\beta}_{\mathbf{1}} \text { CCC_DM1 } \mathbf{1}_{i t}+\beta_{2} \text { ROA }_{i t}+\beta_{3} \operatorname{Ln}(\text { SALES })_{i t}+\varepsilon_{i t} \\
& \text { USLIST }_{i t}=\alpha+\boldsymbol{\beta}_{\mathbf{1}} \text { CCC_DM2 }_{i t}+\beta_{2} R_{2} O A_{i t}+\beta_{3} \operatorname{Ln}(S A L E S)_{i t}+\varepsilon_{i t}
\end{aligned}
$$

The sample period is from 2002 to 2006 . Industries are defined by two-digit industry group (Item 6011) in Worldscope. Financial industries (Item 6011 between 4310 and 4395) are excluded. USLIST is an indicator variable, which equals one for firms domiciled in the U.K. and listed on the U.S. markets, and zero for firms domiciled in the U.K. and listed on the U.K. markets. Cash conversion cycle is calculated as days' sales outstanding (accounts receivable divided by daily sales) plus days' sales in inventory (inventory divided by daily cost of goods sold) minus days' sales in payables (accounts payable divided by daily cost of goods sold). CCC_DM1 is firms' cash conversion cycle minus industry average cash conversion cycle, where industry average cash conversion cycle is computed every year using the firms domiciled in the U.K. and listed on the U.K. markets. CCC DM2 is firms' cash conversion cycle minus industry average cash conversion cycle, where industry average cash conversion cycle is computed every year using the firms domiciled in the U.K. and listed in the U.S. and U.K. markets. Return on assets (ROA) is operating income (Item 1250) divided by total assets (Item 2999). SALES is net revenue in US\$ millions (Item 7240/\$1,000,000) and $\mathrm{Ln}(\mathrm{SALES})$ is the logarithm of SALES. $T$-statistics and Wilcoxon $z$-statistics for the differences in mean and median are reported in the parentheses. In panel B, CCC, CCC_DM1, and CCC_DM2 are scaled by 100 . The numbers in the parentheses are chi-square statistics. ${ }^{* * *},{ }^{* *}$, and ${ }^{*}$ denote statistical significance at 0.01 , 0.05 , and 0.10 levels, respectively, using a two-tailed test. 
Table 6

Impact of Change in Reporting Frequency in the United States on the Proportion of Public Firms

\begin{tabular}{|l|c|c|c|}
\hline \multirow{2}{*}{ Explanatory Variables } & \multicolumn{3}{|c|}{$\begin{array}{c}\text { Dependent Variable } \\
\text { [NTERCEPT }\end{array}$} \\
\hline INROPORTION / (1- PROPORTION)]
\end{tabular}




\section{Table 6}

\section{(continued)}

This table presents the regression results from Regression (6):

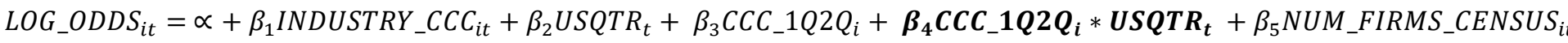

$$
\begin{aligned}
& +\beta_{6} \operatorname{Ln}(\text { INDUSTRY_SALES })_{i t}+\beta_{7} \text { INDUSTRY_GPM }_{i t}++\boldsymbol{\varepsilon}_{i t}
\end{aligned}
$$

Industries are defined by four-digit SIC code. NUM_FIRMS_CENSUS ${ }_{\mathrm{it}}$ is the number of all firms (in thousands), both private and public, obtained from the Census of Manufactures. As U.S. Census of Manufactures takes place every five years, we use the census data from a given year, not only for that year, but also for the two years immediately before and after it. The proportion of public firms (PROPORTION ${ }_{i t}$ ) is the percentage of public firms (obtained from Compustat) relative to NUM_FIRMS_CENSUS it $_{\text {it }}$ for a given industry-year. The log odds of the proportion of public firms (LOG_ODDS it $_{\text {) }}$ is measured as $\mathrm{Ln}_{\text {PRROPORTION }}$ / / (1-PROPORTION $\left.\mathrm{it}_{\mathrm{it}}\right)$. INDUSTRY_CCC $\mathrm{it}_{\mathrm{t}}$ is the median length of the cash conversion cycles of public firms in year $t$ for a given industry, where the cash conversion cycle is calculated as days' sales outstanding (accounts receivable divided by daily sales) plus days' sales in inventory (inventory divided by daily cost of goods sold) minus days' sales in payables (accounts payable divided by daily cost of goods sold). USQTR $\mathrm{t}_{\mathrm{t}}$ is an indicator variable, which equals one if the year is between 1970 and 1974, and zero if the year is between 1965 and 1969 . CCC_1Q2Q $Q_{i}$ is an indicator variable, which equals one if the industry median cash conversion cycle measured between 1965 and 1969 is longer than one quarter and shorter than two quarters, and zero otherwise. INDUSTRY_GPM $\mathrm{it}_{\mathrm{t}}$ is the average gross profit margin of public firms in year $t$ for a given industry. Ln(INDUSTRY_SALES $\mathrm{it}_{\mathrm{it}}$ ) is the logarithm of the average sales (in US\$ millions) of public firms in year $t$ for a given industry. The $t$-statistics (in parentheses) are adjusted for two-way cluster-robust standard errors (clustered by industry and year). ${ }^{* * *},{ }^{* *}$, and ${ }^{*}$ denote statistical significance at $0.01,0.05$, and 0.10 levels, respectively, using a two-tailed test. 
Table 7

Percentage of Firms in Groups Partitioned by Industry Median Cash Conversion Cycle

\begin{tabular}{|c|c|c|c|c|c|c|c|}
\hline & \multicolumn{3}{|c|}{ U.K. } & \multicolumn{3}{|c|}{ United States } & \multirow[t]{2}{*}{$\begin{array}{l}\text { Difference-in- } \\
\text { Differences }\end{array}$} \\
\hline & $2002-2006$ & 2007-2011 & Diff. & 2002-2006 & 2007-2011 & Diff. & \\
\hline INDUSTRY_CCC $<1$ quarter & 0.835 & 0.846 & $\begin{array}{l}0.011 * * \\
(2.021)\end{array}$ & 0.798 & 0.797 & $\begin{array}{c}-0.001 \\
(-0.208)\end{array}$ & $\begin{array}{l}0.012 * \\
(1.782)\end{array}$ \\
\hline 1 quarter $<=$ INDUSTRY_CCC $<=2$ quarters & 0.163 & 0.152 & $\begin{array}{l}-0.011 * \\
(-1.957)\end{array}$ & 0.201 & 0.201 & $\begin{array}{c}0.000 \\
(0.227)\end{array}$ & $\begin{array}{l}-0.011 * \\
(-1.735)\end{array}$ \\
\hline 2 quarters < INDUSTRY_CCC & 0.002 & 0.002 & $\begin{array}{c}0.000 \\
(0.687)\end{array}$ & 0.001 & 0.002 & $\begin{array}{c}0.001 \\
(0.178)\end{array}$ & $\begin{array}{c}-0.001 \\
(-0.547)\end{array}$ \\
\hline $\mathrm{N}$ & 9,148 & 8,069 & & 42,859 & 38,063 & & \\
\hline
\end{tabular}

This table presents the percentage of U.K. and U.S. firms in the three groups partitioned by industry median cash conversion cycle (INDUSTRY_CCC), which is measured using all U.K. observations in Worldscope between 2000 and 2006, when semi-annual reporting was required. Cash conversion cycle is calculated as days' sales outstanding (accounts receivable divided by daily sales) plus days' sales in inventory (inventory divided by daily cost of goods sold) minus days' sales in payables (accounts payable divided by daily cost of goods sold). Industries are defined by two-digit industry group (Item 6011) in Worldscope. Financial industries (Item 6011 between 4310 and 4395 ) are excluded. The numbers in parentheses are $t$-statistics. ${ }^{* * *}{ }^{* *}$, and ${ }^{*}$ denote significance at $0.01,0.05$, and 0.10 levels, respectively, using a two-tailed test. 
Table 8

Difference-in-Differences Comparison of Change in Industry Distributions between the U.K. and the United States

\begin{tabular}{|c|c|c|c|}
\hline & $\begin{array}{l}\text { Dependent variable } \\
=\text { = CCC_1Q }\end{array}$ & $\begin{array}{l}\text { Dependent variable } \\
\text { = CCC_1Q2Q }\end{array}$ & $\begin{array}{c}\text { Dependent variable } \\
=\text { = CCC_2Q }\end{array}$ \\
\hline Intercept & $\begin{array}{l}-20.775^{* * *} \\
(3,587.85)\end{array}$ & $\begin{array}{l}22.628 * * * \\
(4,015.13)\end{array}$ & $\begin{array}{c}-237.000 * * * \\
(367.86)\end{array}$ \\
\hline UK & $\begin{array}{l}1.074 * * * \\
(939.43)\end{array}$ & $\begin{array}{l}-1.156 * * * \\
(1,056.77)\end{array}$ & $\begin{array}{l}0.573 \\
(0.16)\end{array}$ \\
\hline UKQTR & $\begin{array}{c}-0.471 * * * \\
(587.31)\end{array}$ & $\begin{array}{l}0.512 * * * \\
(680.17)\end{array}$ & $\begin{array}{l}-2.820 * * * \\
(97.19)\end{array}$ \\
\hline UK*UKQTR & $\begin{array}{c}\mathbf{0 . 2 9 3} * * * \\
(38.84) \\
\end{array}$ & $\begin{array}{c}-0.307 * * * \\
(41.83) \\
\end{array}$ & $\begin{array}{l}-2.608 \\
(0.15) \\
\end{array}$ \\
\hline INDUSTRY_GPM & $\begin{array}{l}3.294 * * * \\
(1,463.81) \\
\end{array}$ & $\begin{array}{l}-3.534 * * * \\
(1,656.75) \\
\end{array}$ & $\begin{array}{c}27.548 * * * \\
(208.40) \\
\end{array}$ \\
\hline Ln(INDUSTRY_SALES) & $\begin{array}{l}1.004 * * * \\
(3,966.67)\end{array}$ & $\begin{array}{l}-1.090 * * * \\
(4,397.35)\end{array}$ & $\begin{array}{l}9.917 * * * \\
(359.05)\end{array}$ \\
\hline $\mathrm{N}$ & 98,139 & 98,139 & 98,139 \\
\hline
\end{tabular}

This table presents the logistic regression results from Regression (7):

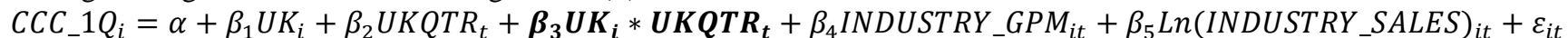

$$
\begin{aligned}
& \text { CCC_1Q2 } Q_{i}=\alpha+\beta_{1} U K_{i}+\beta_{2} U_{K Q T R}+\boldsymbol{\beta}_{3} \boldsymbol{U} \boldsymbol{K}_{\boldsymbol{i}} * \boldsymbol{U K Q T R \boldsymbol { R } _ { \boldsymbol { t } }}+\beta_{4} \text { INDUSTRY_GPM }{ }_{i t}+\beta_{5} \text { Ln }(\text { INDUSTRY_SALES })_{i t}+\varepsilon_{i t} \\
& \text { CCC_2 } Q_{i}=\alpha+\beta_{1} U K_{i}+\beta_{2} U K Q T R_{t}+\boldsymbol{\beta}_{3} \boldsymbol{U K}_{\boldsymbol{i}} * \boldsymbol{U} \boldsymbol{K} \boldsymbol{Q} \mathbf{T} \boldsymbol{R}_{\boldsymbol{t}}+\beta_{4} I N D U S T R Y{ }_{-} G P M_{i t}+\beta_{5} \operatorname{Ln}(\text { INDUSTRY_SALES })_{i t}+\varepsilon_{i t}
\end{aligned}
$$

CCC_1Q, CCC_1Q2Q, and CCC_2Q are indicator variables that equal one if the firm belongs to industries whose median cash conversion cycle (INDUSTRY_CCC) is less than one quarter, between one quarter and two quarters, or more than two quarters, respectively, and zero otherwise. INDUSTRY_CCC is measured using all U.K. observations in Worldscope between 2002 and 2006, when semi-annual reporting was required. Cash conversion cycle is calculated as days' sales outstanding (accounts receivable divided by daily sales) plus days' sales in inventory (inventory divided by daily cost of goods sold) minus days' sales in payables (accounts payable divided by daily cost of goods sold). UK is an indicator variable that equals one for U.K. firms and zero for U.S. firms. UKQTR is an indictor variable that equals one for observations between 2007 and 2011, and zero for observations between 2002 and 2006. INDUSTRY_GPM is the average gross profit margin ((Item 1001 - Item1051)/Item1001) of public firms in a given industry. Ln(INDUSTRY_SALES) is the logarithm of the average sales (Item 7240) of public firms in a given industry. Industries are defined by two-digit industry group (Item 6011) in Worldscope. Financial industries (Item 6011 between 4310 and 4395) are excluded. The numbers in parentheses are chi-square statistics. ${ }^{* * *},{ }^{* *}$, and ${ }^{*}$ denote statistical significance at $0.01,0.05$, and 0.10 levels, respectively, using a two-tailed test. 